\title{
Lobster Distribution and Biodiversity on the Continental Shelf of Brazil: A Review
}

\author{
Raul Cruz ${ }^{1, * \mathbb{D}}$, Marina T. Torres ${ }^{1}$, João V. M. Santana ${ }^{2}$ and Israel H. A. Cintra ${ }^{3}$ \\ 1 Fundação Cearense de Apoio ao Desenvolvimento Científico e Tecnológico, Av. Oliveira Paiva 941, \\ Cidade dos Funcionários, Fortaleza 60822-130, Brazil; marinatorresrodriguezm@gmail.com \\ 2 Instituto Federal de Educação, Ciências e Tecnologia do Ceará (IFCE), Campus de Acaraú. Av. Des. Armando \\ de Sales Louzada, s/n, Acaraú 60000-000, Brazil; joao.vicente@ifce.edu.br \\ 3 Instituto Socioambiental e dos Recurso Hídricos, Universidade Federal Amazonia (UFRA), Ave. Presidente \\ Tancredo Neves, Belém 60000-000, Brazil; israel.cintra@ufra.edu.br \\ * Correspondence: rcruzizquierdo@gmail.com
}

Citation: Cruz, R.; T. Torres, M.; Santana, J.V.M.; Cintra, I.H.A. Lobster Distribution and Biodiversity on the Continental Shelf of Brazil: A Review. Diversity 2021, 13, 507. https:// doi.org/10.3390/d13110507

\section{Academic Editors:}

Patricia Briones-Fourzán, Michel E. Hendrickx and Michael Wink

Received: 28 August 2021

Accepted: 15 October 2021

Published: 20 October 202

Publisher's Note: MDPI stays neutral with regard to jurisdictional claims in published maps and institutional affiliations.

Copyright: (c) 2021 by the authors. Licensee MDPI, Basel, Switzerland. This article is an open access article distributed under the terms and conditions of the Creative Commons Attribution (CC BY) license (https:// creativecommons.org/licenses/by/ $4.0 /)$.

\begin{abstract}
The continental shelf of Brazil is home to a wide range of lobster species, with varying body size, color, habitat preference, and geographic and bathymetric distribution. Spiny lobsters (Panulirus) and slipper lobsters (Scyllaridae) are exploited for export and for the domestic market. Deep sea lobsters (Nephropidae and Polychelidae) have no commercial potential, and little is known about their biology. In this review, we identified 24 lobster species from benthic ecosystems off Brazil (Palinuridae 25\%, Scyllaridae 29\%, Nephropidae 25\%, Polychelidae 17\%, Enoplometopidae 4\%). We designed a simplified theoretical scheme to understand the role of lobsters in the ecosystem, based on available evidence of distribution, biodiversity, life cycle, connectivity, and abundance. Finally, we propose a theoretical scheme of trophic top-down control, with interactions between a large decapod (spiny lobster), a demersal predator (red snapper), an apex predator (small tuna), benthic invertebrates and fishing exploitation.
\end{abstract}

Keywords: lobster; life cycle; predator-prey; food chain; Brazil

\section{Introduction}

A highly coveted marine resource for over 100 years, marine lobsters sustain one of the most profitable artisanal fishing industries in the world. In Brazil, exports of whole lobster were on the rise since 2013, with USD 92.46 million in revenues in 2019 [1].

Lobsters fall into several families: spiny lobsters (Palinuridae), slipper lobsters (Scyllaridae), flaming reef lobsters (Enoplometopidae), clawed lobsters (Nephropidae), and blind lobsters (Polychelidae) [2]. Despite their morphological differences, all the above are referred to as 'lobsters'.

Marine lobsters in the tropical western Atlantic belong to three infraorders of crustacean decapods: Achelata Scholtz \& Richter, 1995, Astacidea Latreille, 1802, and Polychelida Scholtz \& Richter, 1995. Achelata includes not only spiny lobsters (family Palinuridae, Latreille 1802), but also slipper lobsters (family Scyllaridae, Latreille 1825) and one species of furry lobster (currently classified in the family Palinuridae). In contrast, Astacidea (Nephropidae Dana, 1852 and Enoplometopidae Saint Laurent, 1988) have chelae on the first three pairs of pereiopods, while Polychelida (Polychelidae Wood-Mason, 1875), known as blind lobsters, have chelae on four or even all five pairs of pereiopods [3,4].

The taxonomy and diversity of marine lobsters in the tropical western Atlantic is reviewed in this paper, lobster feed into areas of ongoing research in Brazil. Worth highlighting is the analysis of lobster diversity and communities published by Silva et al. [5] for the Great Amazon Reef System (GARS). We also provide the first record in the GARS of Scyllarus chacei Holthuis, 1960, based on species with prehatch eggs, extending the geographic range for this species. 
Silva, et al. [4] filled important gaps in our knowledge of crustacean biodiversity on the continental shelf off the Amazon River. Cruz, et al. [6] described the life cycle of spiny lobsters (Panulirus spp.) and connectivity between oceanic regions, but little is known about the dynamics of recruitment and migration and the influence of climate and fisheries on lobster biodiversity $[7,8]$.

Spiny lobsters (Panulirus White, 1847) are heavily exploited in commercial and recreational fisheries in the Wider Caribbean and along the coast of Brazil. The slipper lobster (Scyllaridae) is occasionally caught as by-catch in spiny lobster traps or shrimp trawls and sold on the Brazilian domestic market. In the waters off southern Brazil, clawed lobsters are a common by-catch in shrimp trawls. The species Metanephrops rubellus (Moreira, 1903), sometimes referred to as langoustine, Uruguayan lobster, or deep-sea lobster, is a valuable export commodity [9].

Fishing, coastal infrastructure developments, and water pollution are the anthropogenic factors that most impact marine ecosystems. Pollution is most harmful to organisms in the early stages of the life cycle (eggs, larvae, nursery areas, juveniles). Urban developments modify the natural biotope (coastal area), with repercussions on migration, spawning, and nurseries. Fishing directly or indirectly alters and degrades marine ecosystems (especially in coastal regions where it tends to be more intense and combined with other anthropogenic disturbances) and the depletion of fishing stocks poses a threat to biodiversity [10]. In such scenarios, trophic and nontrophic interactions may be severely compromised [11], as observed for decapods [12].

In Brazil, with the enforcement of management measures in the period 2012-2020, fishing pressure on spiny lobster stocks decreased and a tendency for recovery was observed [13]. However, using a variety of methods and gear (for example, rectangular baited traps with one or two entrances and bottom gillnets [14]), artisanal lobster fishermen still cause significant damage to benthic habitats and the depletion of nontarget species [15]. In addition, artificial shelters ('marambaias') of varying design were since 2000 deployed on fishing grounds off northeastern Brazil [16]. As the gear is nonselective, a variety of nontargeted organisms are captured as by-catch (commercial fish, mollusks, crabs, etc.), including species that prey on lobsters. Moreover, fishermen often harvest lobsters from artificial shelters or reefs by hook or hand and using a compressor connected to the boat's motor [17], in detriment to the health of both divers and the benthic ecosystem.

In this review, we address aspects of the distribution, biodiversity, connectivity, length assessment and life cycle of lobster species occurring on the continental shelf of Brazil (CSB). For this reason, we review publications, analyze information on species, search databases, and look into field surveys stratified by depth. Although available information on slipper, clawed, and blind lobsters is scarce, limiting our knowledge of their biology, ecology, and population dynamics, we believe the material gathered and discussed in this review is highly relevant for both researchers and fishing resource managers in Brazil. We also look at time series of spiny lobster and red snapper landings to understand more about predator-prey interactions. Finally, we identify major knowledge gaps and offer suggestions for future studies on this emerging and highly promising research topic.

\section{Material and Methods}

\subsection{Lobster Site Description}

Lobsters are distributed throughout the Brazilian continental shelf (CSB) from Amapá $\left(04^{\circ} 26^{\prime} \mathrm{N} 51^{\circ} 32^{\prime} \mathrm{W}\right)$ to Rio Grande do Sul $\left(29^{\circ} 46^{\prime} \mathrm{S} 53^{\circ} 10^{\prime} \mathrm{W}\right)$. Lobster stocks are concentrated in four regions along the Brazilian coast: the North (Great Amazon Reef System), the Northeast (NE), the Southeast (SE), and the South (S).

In the North, Moura, et al. [18] described the Great Amazon Reef System (GARS) as a $1000 \mathrm{~km}$-long mesophotic coral reef ecosystem under low-light conditions, located approximately $80 \mathrm{~km}$ from the mouth of the Amazon River and covering about 9,500 km², bridging the gap between the border of Amapá $\left(5^{\circ} \mathrm{N} 1^{\circ} \mathrm{S}\right.$ to $\left.44^{\circ} \mathrm{N} 51^{\circ} \mathrm{W}\right)$ and the coast of Maranhão $\left(0^{\circ} \mathrm{S} 46^{\circ} \mathrm{W}\right.$ to $\left.2^{\circ} \mathrm{S} 41^{\circ} \mathrm{W}\right)$, at a depth of $30 \mathrm{~m}$ to $90-120 \mathrm{~m}$ (shelf break). 
The continental shelf off Northeastern Brazil (NE) $\left(2^{\circ} \mathrm{S} 4^{\circ} \mathrm{W}\right.$ to $9^{\circ} \mathrm{S} 35^{\circ} \mathrm{W}$, Pernambuco) is relatively wide and shallow $(3-60 \mathrm{~m})$, followed by an abrupt drop-off starting at a depth of approximately $60 \mathrm{~m}$. Lobster habitats are diverse, including reef structures and calcareous algae beds, especially off Ceará and Rio Grande do Norte, possibly due to the absence of large rivers and, consequently, small amounts of fluvial discharge [19].

Between Pernambuco and Espirito Santo $\left(9^{\circ} \mathrm{S} 35^{\circ} \mathrm{W}\right.$ to $\left.21^{\circ} \mathrm{S} 40^{\circ} \mathrm{W}\right)$ in Southeastern Brazil (SE), the shelf is narrow and lobster landings are small.

The climate in Southern Brazil (S) ( $34^{\circ} \mathrm{S}$ to $\left.22^{\circ} \mathrm{S}\right)$ is subtropical to temperate, with complex topographic and hydrodynamic regimes. Lobster habitats at varying latitudes and depths of the CSB are often covered with crustose coralline algae (rhodoliths) [20,21]. The entire shelf measures almost $270,000 \mathrm{~km}^{2}$, with a maximum width of $70-230 \mathrm{~km}$ and a break at 100-180 $\mathrm{m}$ depth [22].

\subsection{Length Assessment}

The most accurate way to measure lobsters is by carapace length (CL, the distance between the ridge of the supraorbital spines and the posterior end of the carapace). In this study, we used total length (TL, the distance between the rostrum and the posterior edge of the telson) for the genus Panulirus. Fixed ratios between the different body parts make it possible to convert CL into TL, and vice-versa. Such equations were published by Cruz [23] for the species $P$. argus. The equations are as follows:

(a) Males: $\mathrm{TL}=32.8431+2.5197 * \mathrm{CL}$.

(b) Females: TL $=36.3535+2.5402 *$ CL.

(c) Total (both sexes): $\mathrm{TL}=9.8740+2.9290 *$ CL.

(d) Males: $\mathrm{CL}=-11.7974+0.3925 * \mathrm{TL}$.

(e) Females: $\mathrm{CL}=-2.3439+0.3374 * \mathrm{TL}$

(f) Total (both sexes): CL $=-11.6569+0.3838 *$ TL.

$\mathrm{Wt}=0.002065 \times \mathrm{CL}^{2.7920}$ where $\mathrm{Wt}$ is total weight expressed in grams $(\mathrm{g})$

When the maximum carapace length (MCL) was reported, the above equations were used to convert MCL to MTL (maximum total length).

\subsection{Lobster Data Collection and Time Series}

During fishery trials in the Great Amazon Reef System between 1996 and 1998, lobsters were collected with bottom trawl shrimp nets at different times of the day and night, on different types of sediments, and stratified by depth $(41-626 \mathrm{~m})$, as part of the REVIZEE Program (Assessment of Sustainable Potential of Living Resources in the Exclusive Economic Zone). The species were identified at the CEPNOR Crustacean Laboratory and were deposited in the collection of crustaceans of the National Center for Research and Conservation of Northern Marine Biodiversity (CEPNOR) and the Chico Mendes Institute for Biodiversity Conservation (ICMBio). The species were classified according to the check list of marine lobsters by Chan [24] and the guidelines by Silva et al. [4,5], and grouped by family (Palinuridae, Scyllaridae, Nephropidae and Polychelidae) and depth. The sex of each specimen was determined, whereas the total length (TL) and carapace length (CL) were measured with a $300 \mathrm{~mm}$ Vernier caliper.

In the period of 1999-2000, monthly random field surveys were undertaken on the fishing grounds off Ceará at $10-50 \mathrm{~m}\left(2^{\circ} 53^{\prime} 22^{\prime \prime} \mathrm{S} 41^{\circ} 13^{\prime} 46^{\prime \prime} \mathrm{W}\right.$ to $4^{\circ} 06^{\prime} 06^{\prime \prime} \mathrm{S} 38^{\circ} 08^{\prime} 56^{\prime \prime}$ W) using traps and gillnets. The total size composition of lobsters caught with traps and gillnets in shallow waters was used to calculate the maximum carapace length of the target groups (the genus Panulirus and the family Scyllaridae).

In both regions, maximum body length was recorded for each lobster species, with habitats stratified by depth, to determine the maximum growth age. When only one specimen was available, its length was used as maximum value.

Currently, annual lobster landing data (1960-2020) are provided by major fishing companies, exporters, and producers affiliated with Sindfrio (a union of fishing industries and cold chains in the State of Ceará), representing $63 \%$ of the national lobster industry in 
2018-2020. Figures from nonmember fishing companies were obtained from the Comex Stat database. Brazilian government agencies no longer keep yearly updated databases of red snapper (Lutjanus purpureus, Poey, 1866) landings, but a time series is available for the period 1960-2004.

To test for possible associations between red snapper and Brazilian red spiny lobster Panulirus argus (Latreille, 1804) production, we performed a cross-correlation analysis [25] of the annual production ( $t$ ) and the lag tendency. Diggle [25] suggested the approximate formula $2 / \sqrt{ } \mathrm{n}$, where $\mathrm{n}$ is the total number of months $(n=34)$, to assess the significance at $95 \%$ of the cross-correlation function if the calculated value exceeds the equation.

\section{Results and Discussion}

\subsection{Connectivity of Spiny Lobsters (Panulirus spp.)}

Available evidence from Cruz, et al. [6] supports the hypothesis that the P. argus pueruli found in the Lesser Antilles originate from larvae carried by rings of the North Brazil Current. In addition, phyllosomata of the green spiny lobster Panulirus laevicauda (Latreille, 1817) collected in the Caribbean Sea constitute compelling evidence of southto-north connectivity between lobster populations in the Western Atlantic, contradicting the view that the Amazon River and the Orinoco River represent insurmountable biogeographic barriers [3]. This is supported by the fact that P. laevicauda is more abundant in Brazil than in the Caribbean and by the discovery by Rocha et al. [26] that populations of Halichoeres radiatus (Linnaeus, 1758) (Labridae) in the Caribbean and at offshore islands in the southwestern Atlantic are genetically identical.

The complex life cycle of spiny lobsters involves the occupation of habitats on continental and insular shelves, islands, and banks. Due to their year-round reproductive activity, large patches of phyllosomata of variable density are constantly moving with the currents, coinciding with the plankton distribution $[6,8]$. Current observations allow to infer that (i) larval recruitment is inversely associated with the Amazon-Orinoco River discharge, (ii) the range of salinity required for phyllosoma survival (33-35\%o) is compatible with the salinity gradients reported for oceanic waters, and (iii) the North Brazil Current retroflexion supports self-recruitment [6]. Conceivably, patches of lobster larvae become trapped in the GARS and NE, leading to larval transport, puerulus settlement, and self-recruitment.

The biogeographic barrier adduced to explain allopatric speciation, as in the case of the newly proposed species Panulirus meripurpuratus [27], does not seem to prevent regular larval migration from south to north, as previously claimed by Sarver et al. [28,29]. It should be kept in mind that the GARS is an extensive mesophotic reef ecosystem at a depth between 50 and $100 \mathrm{~m}$, located approximately $80 \mathrm{~km}$ from the mouth of the Amazon River and heavily exploited for fish and lobster [18].

The fact that the Brazilian lobster species P. meripurpuratus was caught in Venezuela and Florida [29], Buck Island St Croix, USVI (pers. comm. by Tom Mathews) and in the Mexican Caribbean [30] makes it difficult to sustain the segregation hypothesis of Giraldes \& Smyth [27] (Figure 1). The presence of this species in the Caribbean region raises the possibility of hybridization between species or subspecies. We also looked into the possible existence in Brazil of hybrids between sympatric lobster species of the genus Panulirus, as suggested by differences in color patterns and morphology [6]. To help understand the relationship between size, feeding behavior, and nutrition preferences stratified by depth, more research on carotenoid pigments in the carapace, abdomen, and legs would be useful.

Most available biogeographic maps of panulirid species [27] are inexplicit and do not show in detail how biological taxa are spatially distributed, whereas the information gathered by Cruz, et al. [6] provides a fairly reliable picture of the abundance, distribution, and depth preferences of each species. The incorporation of data from fishing expeditions allows a more realistic view of the dynamics of lobster stocks in Brazil and the Wider Caribbean (Figure 1). The question marks on the maps (Figure 1A) indicate the absence of lobsters, contradicting the actual distribution of the species in the GARS (Figure 1C). 


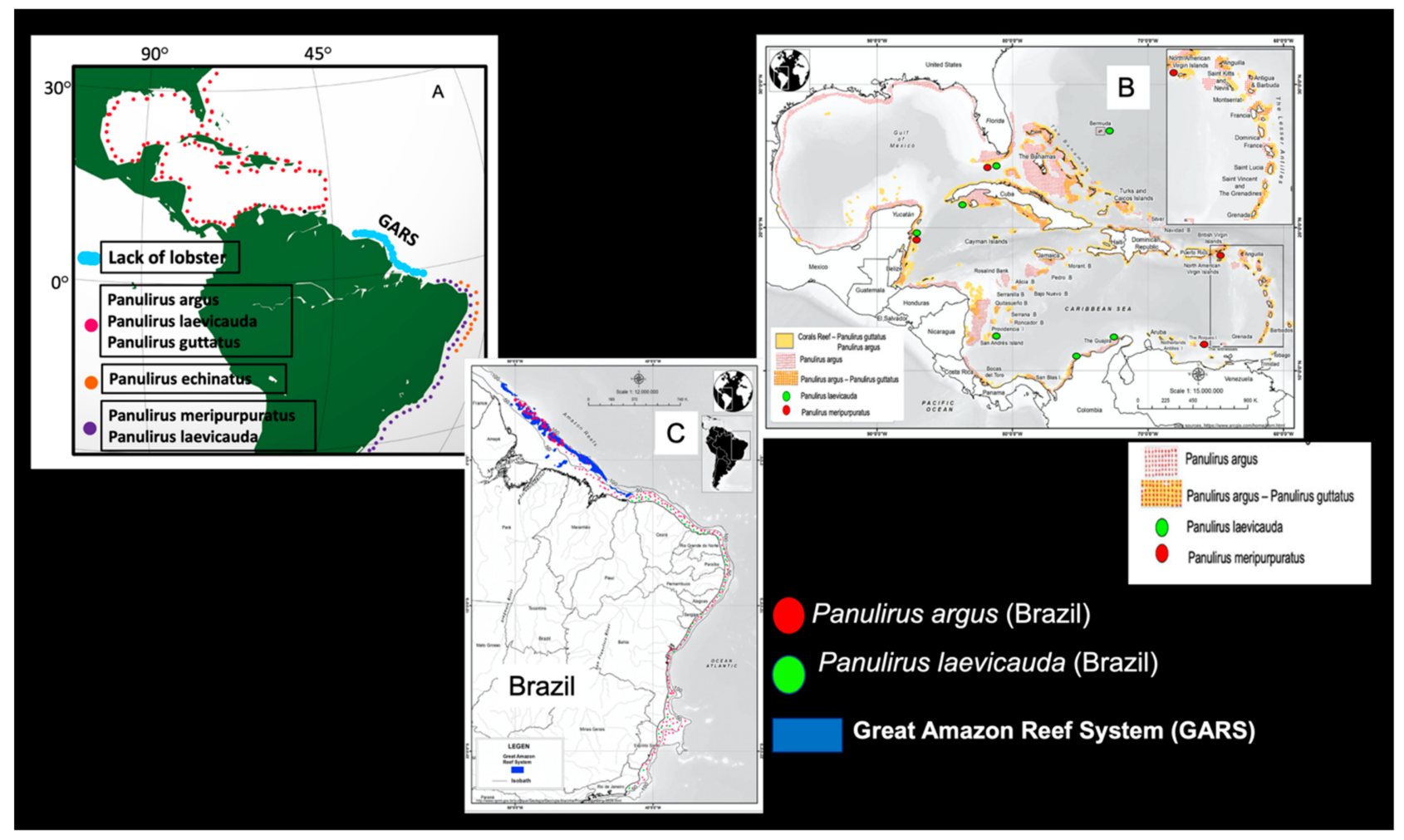

Figure 1. Spatial distribution of lobsters of genus Panulirus (White, 1847). (A) Map adapted from Giraldes \& Smyth [27]. (B) Map adapted from Cruz et al. [6]. (C) Map adapted from Cruz et al. [13].

However, since the Caribbean spiny lobster and P. meripurpuratus are not completely segregated geographically, we believe the hypothesis of oceanic connectivity (spiny lobster larvae migrating between populations on either side of the Amazon River) is warranted and lends support to the paradigm of two subspecies. Giraldes \& Smith [27] did not present compelling evidence to substantiate the notion of two different panulirid species, and genetic data alone are insufficient to redefine a species; in fact, the use and interpretation of genetic data depend on our concept of species [31]. We therefore chose to employ the name P. argus for both the Brazilian form of red spiny lobster and the form of Caribbean spiny lobster which occurs in the Wider Caribbean.

The co-occurrence of P. argus and P. laevicauda in the same geographic regions needs to be investigated with molecular analysis and morphological comparisons between species collected in the north and south of GARS, NE, SE, and in different regions of the Caribbean (Mexico Caribbean, Florida, the Colombian continental coast and the Lesser Antilles). Such studies will help clarify the identity of species and potential subspecies.

\subsection{Lobster Distribution and Diversity}

The benthic ecosystems along the Brazilian coast are inhabited by at least 24 lobster species belonging to 5 families, most importantly Palinuridae (6 species; $25 \%$ ) and Scyllaridae (7 species; 29\%). Nephropidae (25\%) includes 6 species and 3 genera. Polychelidae $(17 \%)$ (deep-sea blind lobsters) is represented by 4 species, and Enoplometopidae is represented by one ( $4 \%$ ). These 24 species are widely distributed on the CSB.

Recently, Silva, et al. $[4,5]$ surveyed the lobster populations of the deep waters of the GARS. The Brazilian form of P. argus is the most exploited panulirid in the Northern and Central GARS [5], while Palinustus truncatus A. Milne Edwards, 1880 is rarely captured [32] (Figure 2) and P. laevicauda and Panulirus echinatus Smith, 1869 (painted lobster) are absent in this region. Inshore habitats are unattractive for lobsters due to low salinity and $\mathrm{pH}$, turbidity, and silt from the Amazon River [18]. Juveniles and adults are absent from coastal waters [6]. 


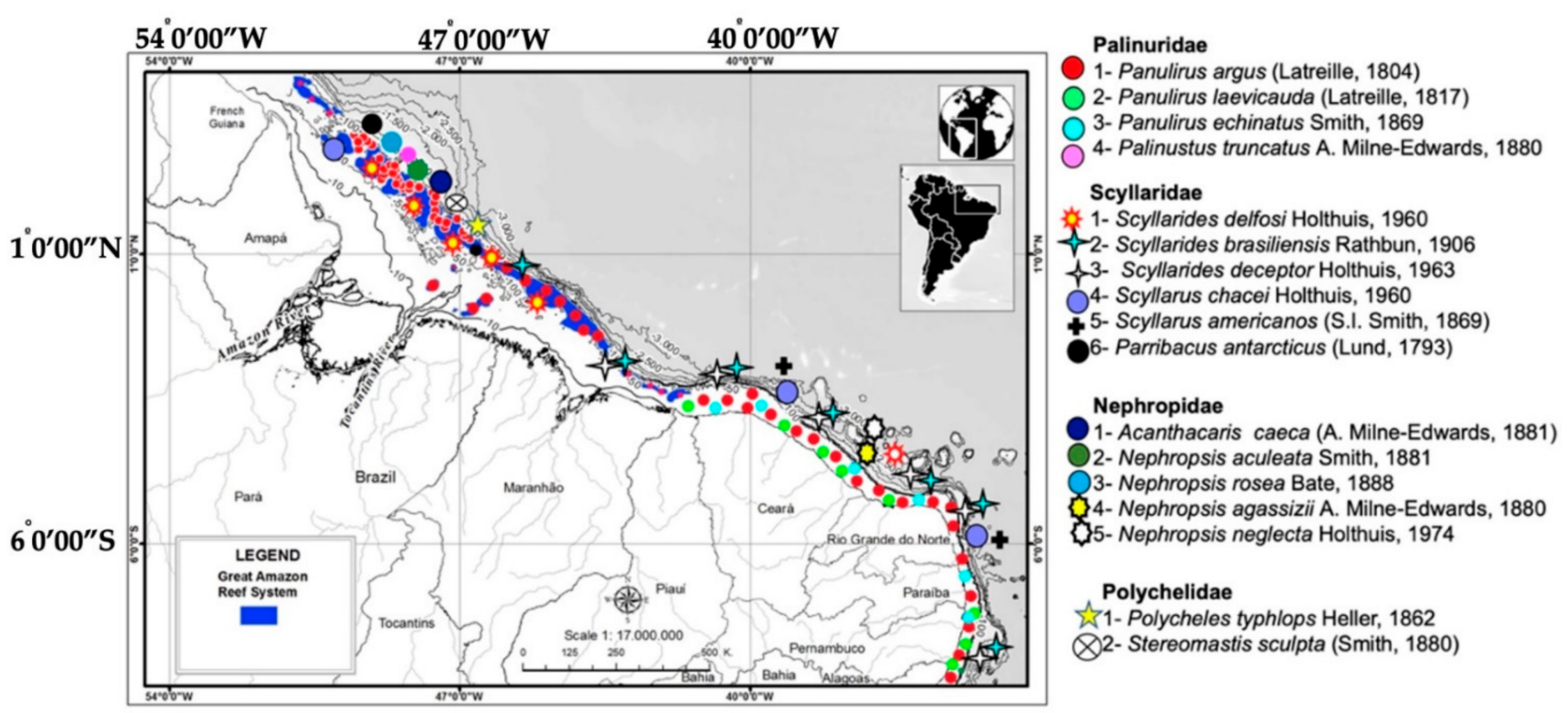

Figure 2. Spatial distribution and diversity of lobsters in Great Amazon Reef System (GARS) and in northeastern section (NE) of continental shelf of Brazil (CSB).

The genus Scyllarides is represented by 13 species [33] distributed worldwide. The slipper lobsters Scyllarides delfosi Holthuis, 1960, Parribacus antarcticus (Lund, 1793) (Figure 2), Scyllarides brasiliensis Rathum, 1906, and Scyllarides deceptor Holthuis, 1963 occur in NE and SE, from Maranhão to São Paulo [34,35], although Tavares et al. [36] included the coastline between Rio de Janeiro and Buenos Aires $\left(23.5^{\circ} \mathrm{S}\right.$ to $\left.39^{\circ} \mathrm{S}\right)$ in the distribution and reported taxonomic differences between slipper lobsters of similar color patterns (Figures 2 and 3). These lobsters are caught incidentally by pink shrimp trawlers [36-38]. Scyllarus ramosae [39] is an invalid taxon in Chan [24]. Scyllarides aequinoctialis (Lund, 1793) is common in southern Brazil [3,40], but some authors believe they occur along the entire coast of Brazil [41,42]. Nevertheless, the species is not mentioned in the surveys of Coelho \& Ramos Porto [35], Melo [34], Dall'Occo [43,44], Coelho et al. [45], or Serejo et al. [46]. According to the latter authors, the species is restricted to the wider Caribbean, but genetic analyses are necessary to confirm this.

The genus Scyllarus [47] is restricted to the Atlantic Ocean and comprises nine species, of which four (44\%) were recorded from Brazilian waters: Scyllarus chacei Holthuis, 1960 occurs in the GARS [47], in Bahia and in Rio de Janeiro [43]. Scyllarus americanus (S.I. Smith, 1869) and Scyllarus depressus (S.I. Smith, 1881) are known from SE [39] (Figures 2 and 3).

Nephropidae (clawed lobsters) includes seven species, three of which in the GARS: Acanthacaris caeca (A. Milne-Edwards, 1881), Nephrosis aculeata Smith, 1881, and Nephrosis rosea Bate, 1888). The species Nephrosis agassizii (A. Milne-Edwards, 1880) and Nephrosis neglecta Holthuis, 1974 occur in NE and SE [48], while N. aculeata and N. rosea are reported from SE $[33,43,46,49,50]$ (Figures 2 and 3).

The family Polychelidae (blind lobsters) is represented by four species on the CSB, out of a total of 38 species in the world [51]. Stereomastis sculpta (Smith, 1880) and Polycheles typhlops C. Heller, 1862 are found throughout the GARS [9], but the latter also occurs on the central Brazilian slope ( $11^{\circ}$ to $\left.22^{\circ} \mathrm{S}\right)$, along with Pentacheles laevis Bate, 1878 and Pentacheles validus A. Milne Edwards, 1880 [50] (Figures 2 and 3). Polycheles sculptus [50] is an invalid taxon in Chan [24].

Justitia longimanus H. Milne Edwards, 1837 (Palinuridae) is small and rather uncommon, while Enoplometopus antillensis Lütken, 1865 (Enoplometopidae) occurs in southern Brazil [3]. Finally, Palinurellus gundlachi von Martens, 1878 (Palinuridae) occurs in NE [3,43] from Paraiba to Alagoas. The last two species were first recorded at the marine reserve at Rocas Atoll [52]. 
The Uruguayan lobster (Nephropidae), Metanephrops rubellus (Moreira, 1903), is found between $22^{\circ} \mathrm{S}$ (Rio de Janeiro) and $26^{\circ} \mathrm{S}$ (Paraná) [53] (Figure 3).

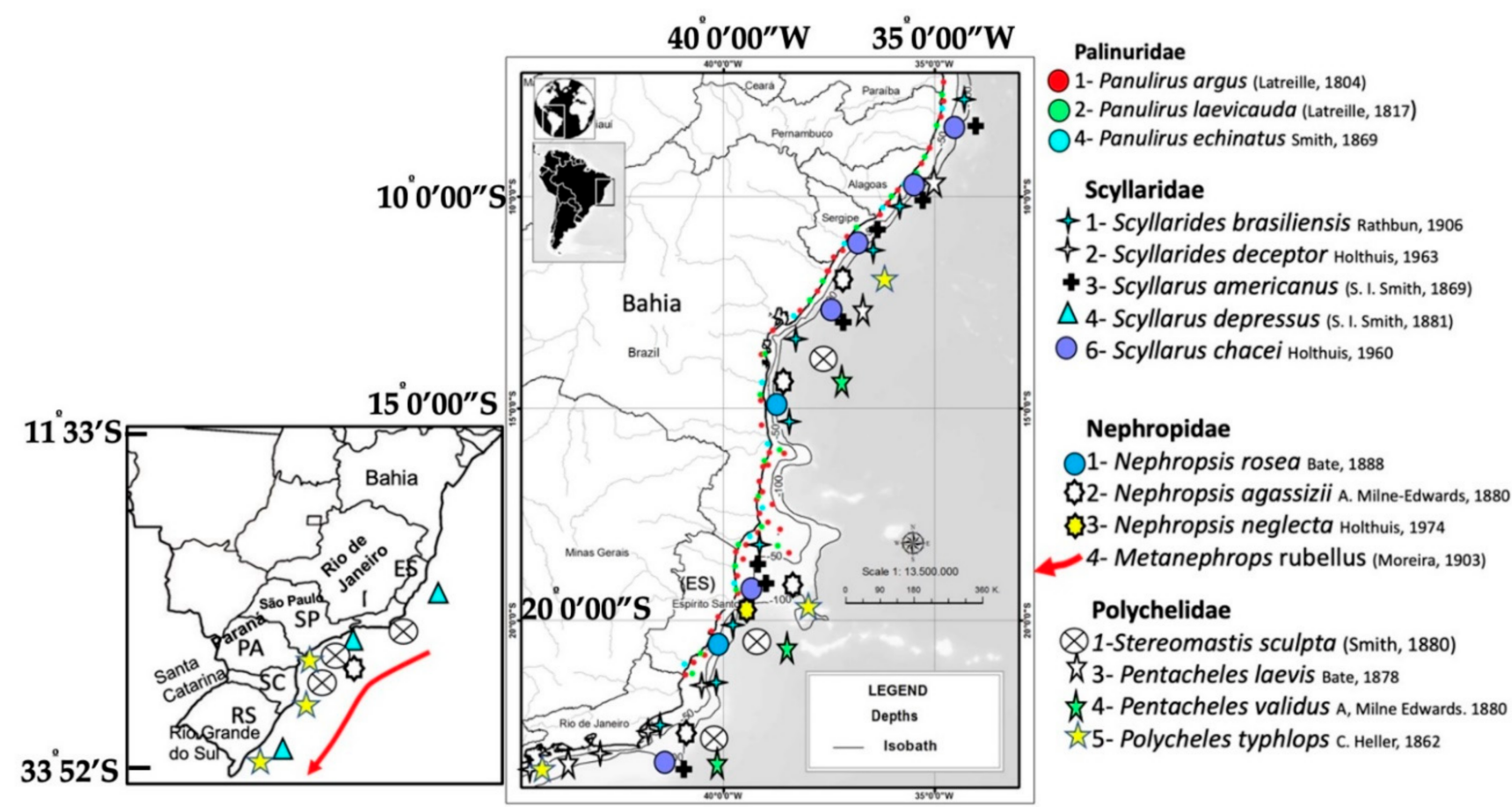

Figure 3. Spatial distribution and diversity of lobsters in southeastern (SE) and southern (S) sections of continental shelf of Brazil (CSB).

Appendix A provides a list of the species surveyed, with author and taxon date. Appendix B credits the source photographs [54-62].

\subsection{Bathymetric Distribution}

With approximately $7491 \mathrm{~km}$ of coastline, the CSB comprises some of the world's most important lobster fishing grounds (Figure 4). S. brasiliensis and the Brazilian form of $P$. argus are the only species found in all environments along the shelf. The main target of commercial fisheries, red spiny lobster, is captured at depths between $40 \mathrm{~m}$ and $110 \mathrm{~m}$ in the GARS [5], and between 10 and $50 \mathrm{~m}$ in NE and SE [6].

$P$. laevicauda and P. echinatus coexist in some regions but differ with regard to depth distribution. The former is found at 1-40 $\mathrm{m}$ (no exploratory survey registered it at depths greater than $50 \mathrm{~m}$ ) [50], while the latter was only observed in shallow waters (1-25 m) and almost always in association with reef structures [34]. P. truncatus, a rare species restricted to the GARS, with no commercial potential [5], prefers deeper waters [50,63,64] (Figure 4).

Lobsters predominantly dwell on substrates of benthic calcareous algae [65], including red algae (Rhodophyceae) and green algae (Chlorophyceae). Slipper lobsters are found at variable depths and on a wide variety of substrates, especially on muddy sand and gravel bottoms and organogenic rock $[5,44]$. Species of the genera Scyllarides and Scyllarus are common on the mesopelagic slope at $200-1000 \mathrm{~m}$, except S. americanus and P. antarcticus (Figure 4).

In southern Brazil, shrimp trawlers catch the species M. rubellus at 50-270 m [53]. The remaining species have no commercial potential and are mostly found between 100 and $1000 \mathrm{~m}$ depth (Figure 4).

Finally, deep-sea blind lobsters (Polychelidae) occur in the GARS and in southeastern and southern Brazil (Figure 4), but very little is known about their life cycles. 


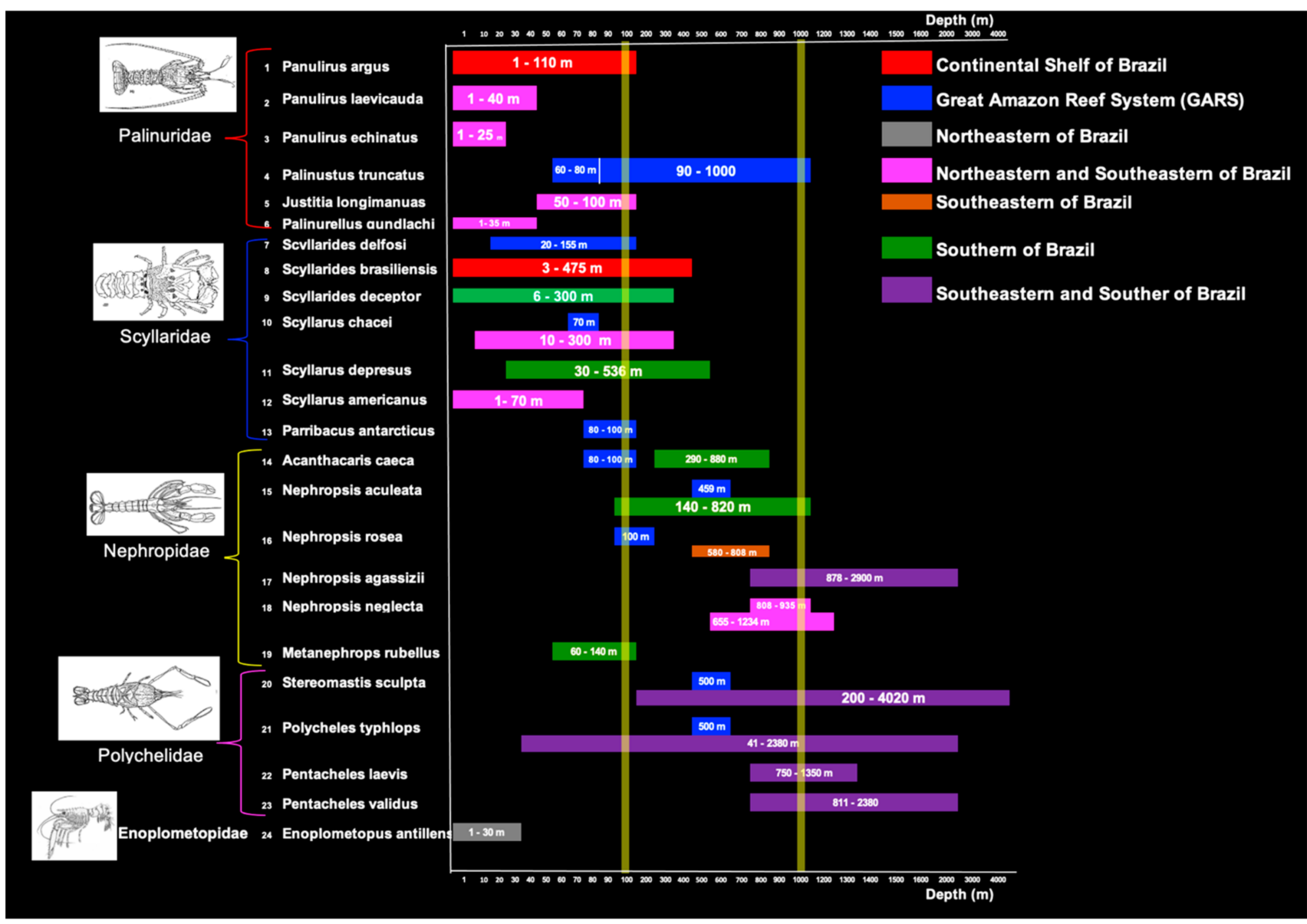

Figure 4. Bathymetric distribution of lobster species according to sector of continental shelf of Brazil (CSB).

\subsection{Maximum Total Length (MTL) of Lobster Species}

Knowledge of the MTL of different lobster species can help researchers to clarify important aspects of bioecology and population dynamics (longevity, clutch size, growth, reproductive potential, predator size, maximum catch size, etc.) and subsidize the implementation of regulatory measures.

The 24 lobster species occurring on the CSB display a wide range of body length (30-620 mm MTL). MTL is not associated with habitat depth (Figure 5, Table 1).

The mean MTL (MTL $\pm 95 \%$ confidence interval) was $313.60 \pm 175.63 \mathrm{~mm}$ (range: 118-620) for Palinuridae, $157.00 \pm 59.67 \mathrm{~mm}$ (range: $30-270$ ) for Scyllaridae, $164.17 \pm 57.17 \mathrm{~mm}$ (range: 110-300) for Nephropidae, and $80.83 \pm 30.71 \mathrm{~mm}$ (range: 47-150) for Polychelidae. The largest mean MTL was that of the genus Panulirus: $433.33 \pm 183.33 \mathrm{~mm}$ (range: 328-620) (Table 1).

Oversized ('giant') red spiny lobsters $(620 \mathrm{~mm}, \mathrm{MTL})$ are the largest crustaceans and the top predators in benthic marine ecosystems on the CSB and possibly in other parts of the Western Tropical Atlantic (Figure 5). For example, animals measuring $802 \mathrm{~mm}$ MTL and weighing $\sim 6 \mathrm{~kg}$ were observed in a marine protected area off Bermuda (Table 1). The giant Brazilian form of P. argus is the most abundant palinurid in Brazil and the keystone of the benthic community. Size, depth, and ecological parameters are strongly associated for red spiny lobsters [6], making it possible to infer that lobster size and prey size are positively correlated [3]. 


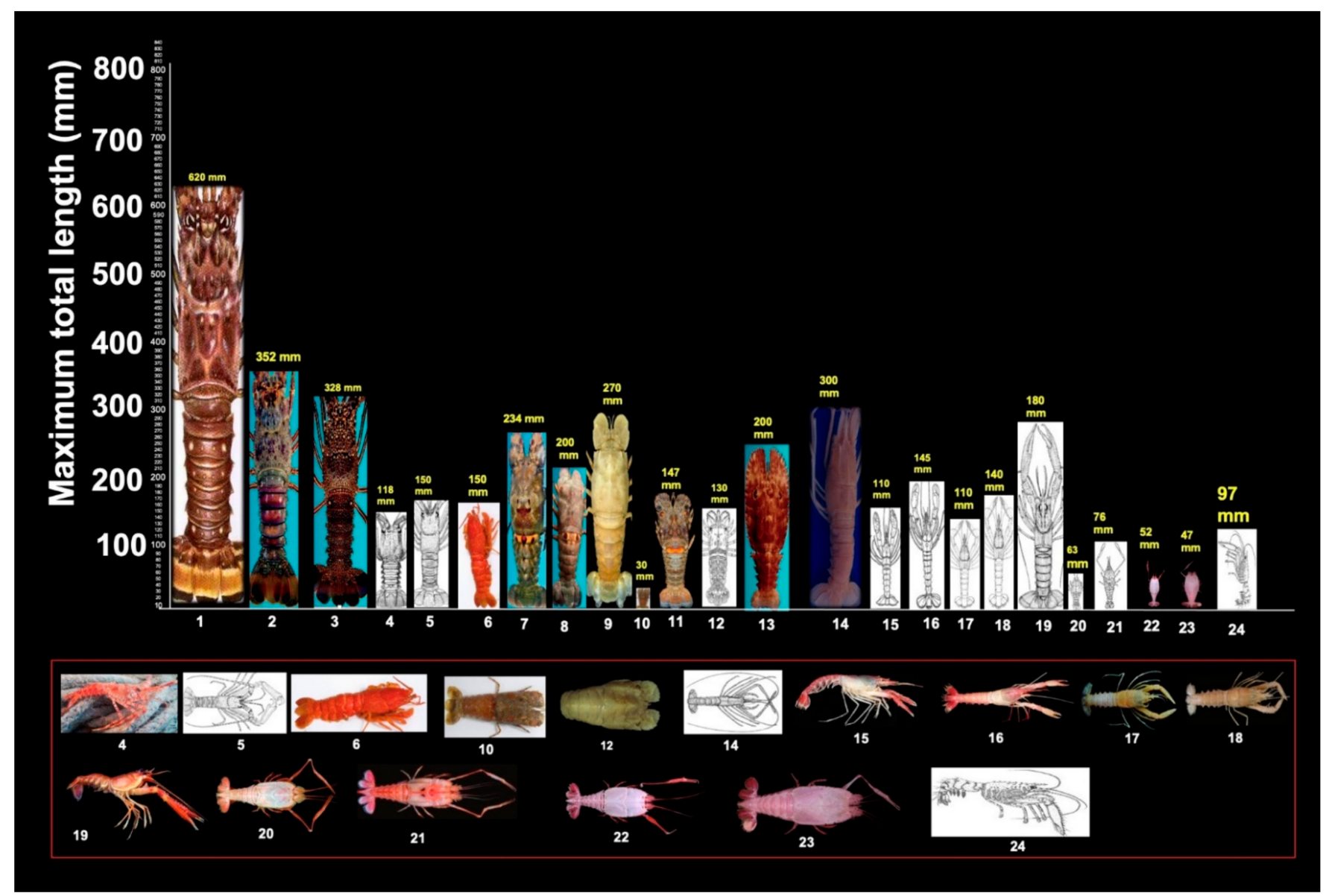

Figure 5. Maximum total length (MTL) of 24 lobster species occurring on continental shelf of Brazil (Table 1). Lower frame features enlarged pictures of small lobster species. Species (Appendix A) were distributed in following families: Palinuridae: 1. Brazilian form of Panulirus argus; 2. Panulirus laevicauda; 3. Panulirus echinatus; 4. Palinustus truncatus; 5. Justitia longimanus, 6. Palinurellus gundlachi. Scyllaridae: 7. Scyllarides delfosi; 8. Scyllarides brasiliensis; 9. Scyllarides deceptor; 10. Scyllarus chacei; 11. Scyllarus depressus; 12. Scyllarus americanus; 13. Parribacus antarcticus. Nephropidae: 14. Acanthacaris caeca; 15. Nephropsis aculeata; 16. Nephropsis rosea; 17. Nephropsis agassizii; 18. Nephropsis neglecta; 19. Metanephrops rubellus. Polychelidae: 20. Stereomastis sculpta; 21. Polycheles typhlops, 1862; 22. Pentacheles laevis; 23. Pentacheles validus. 24. Enoplometopus antillensis.

Table 1. Morphometric measurements of 24 lobster species reported from continental shelf of Brazil: maximum total length (MTL), maximum carapace length (MCL), total weight $(\mathrm{Wt})$, region, depth range $(\mathrm{m})$, and sex.

\begin{tabular}{|c|c|c|c|c|c|c|c|}
\hline Species & $\begin{array}{l}\text { MTL } \\
(\mathrm{mm})\end{array}$ & $\begin{array}{l}\text { MCL } \\
(\mathrm{mm})\end{array}$ & Wt (g) & Region & $\begin{array}{l}\text { Depth } \\
\text { (m) }\end{array}$ & Sex & Reference \\
\hline \multirow{2}{*}{$\begin{array}{l}\text { 1- Brazilian form of } \\
\text { Panulirus argus }\end{array}$} & $620(a)$ & 233 & $3075(b)$ & $\begin{array}{c}\text { Br. } \\
\text { GARS }\end{array}$ & $1-110$ & $\mathrm{M}$ & Data base UFRA, Brazil \\
\hline & $802(a)$ & 302 (b) & 6000 & Ber. & - & M & Internet $(*)$ \\
\hline 2- Panulirus laevicauda & $352(a)$ & 127 & & $\mathrm{Br}$. & $1-40$ & $\mathrm{M}$ & Cruz et al. [13] \\
\hline 3- Panulirus echinatus & $328(a)$ & 115 & & Br. & $1-25$ & M & Cruz et al. [13] \\
\hline 4- Palinustus truncatus & 118 & - & & $\mathrm{Br}$. & $60-1000$ & $\mathrm{~F}$ & Silva et al. [55] \\
\hline 5- Justitia longimanus & 150 & & & Br. & 50-100 & M & Dall'Occo [51] \\
\hline 6- Palinurellus gundlachi & 150 & & & $\mathrm{Cu}$. & $1-35$ & & Cruz et al. [15] \\
\hline 7- Scyllarides delfosi & 234 & & & $\begin{array}{l}\text { Br. } \\
\text { GARS }\end{array}$ & 20-155 & M & Silva et al. [55] \\
\hline
\end{tabular}


Table 1. Cont

\begin{tabular}{|c|c|c|c|c|c|c|c|}
\hline Species & $\begin{array}{l}\text { MTL } \\
(\mathrm{mm})\end{array}$ & $\begin{array}{l}\text { MCL } \\
(\mathrm{mm})\end{array}$ & Wt (g) & Region & $\begin{array}{l}\text { Depth } \\
\text { (m) }\end{array}$ & Sex & Reference \\
\hline 8- Scyllarides brasiliensis & 200 & - & & Br. & $3-475$ & - & Holthuis [3] \\
\hline 9- Scyllarides deceptor & 270 & 101 & & $\mathrm{Br}$. & $6-300$ & $\mathrm{~F}$ & Tavares et al. [16] \\
\hline 10- Scyllarus chacei & 30 & 14 & 12.4 & $\begin{array}{l}\text { Br. } \\
\text { GARS }\end{array}$ & $10-300$ & $\mathrm{~F}$ & Silva et al. [17] \\
\hline 11- Scyllarus depressus & 147 & 27.7 & & $\mathrm{Br}$. & $30-536$ & & Puciarelli \& Rego [18] \\
\hline 12- Scyllarus americanus & 130 & 25.3 & & Br. & $1-70$ & & No restrictions \\
\hline 13-Parribacus antarcticus & 200 & & & Br. & $80-100$ & & Holthuis [3] \\
\hline 14- Acanthacaris caeca & 300 & & & $\begin{array}{l}\text { Br. } \\
\text { GARS }\end{array}$ & $80-880$ & & Silva et al. [10] \\
\hline 15- Nephropsis aculeata & 110 & & & $\begin{array}{c}\text { Br. } \\
\text { GARS }\end{array}$ & $140-820$ & & $\begin{array}{c}\text { Silva et al. [10], } \\
\text { Legal \& Poupin [19] }\end{array}$ \\
\hline 16- Nephropsis rosea & 145 & & & $\begin{array}{c}\text { Br. } \\
\text { GARS }\end{array}$ & $100-808$ & & Silva et al. [10] \\
\hline 17- Nephropsis agassizii & 110 & & & $\begin{array}{c}\text { Br. } \\
\text { GARS }\end{array}$ & 878-2900 & $\mathrm{F}$ & Silva et al. [10] \\
\hline 18- Nephropsis neglecta & 140 & & & Br. & 655-1234 & $\mathrm{F}$ & Alves-Júnior et al. [20] \\
\hline 19-Metanephrops rubellus & 180 & & & Br. & $60-140$ & M & Holthuis [3] \\
\hline 20- Stereomastis sculpta & 63 & & & $\begin{array}{c}\text { Br. } \\
\text { GARS }\end{array}$ & $200-4020$ & & Silva et al. [10] \\
\hline 21- Polycheles typhlops & 76 & & & $\begin{array}{l}\text { Br. } \\
\text { GARS }\end{array}$ & $41-2380$ & & Silva et al. (10] \\
\hline 22- Pentacheles laevis & 52 & & & $\mathrm{Br}$. & $750-1350$ & & Serejo et al. [53] \\
\hline 23- Pentacheles validus & 47 & & & Br. & $811-2380$ & & Serejo et al. [53] \\
\hline $\begin{array}{l}\text { 24- Enoplometopus } \\
\text { antillensis }\end{array}$ & 97 & & & $\mathrm{Br}$. & $1-30$ & & Holthuis [3] \\
\hline
\end{tabular}

$(\mathrm{a}, \mathrm{b})=$ see Section 2 (2.4. Maximum total length). Legends: $\mathrm{Br}=$ Brazil; Ber $=$ Bermuda; GARS = Great Amazon Reef System; $\mathrm{Cu}=$ Cuba. $\mathrm{M}=$ male and $\mathrm{F}=$ female. $\left(^{*}\right) \mathrm{https}: / /$ www.washingtonpost.com/news/local/wp/2016/10/18/huge-14-pound-lobstercaught-in-bermuda-after-hurricane/, accessed on 15 August 2021.

Interspecific competition is assumed to have a strong influence on lobster population dynamics, although this is not easily demonstrated in the wild. In any case, the number of competitors for food and natural shelter decreases at depths below $50 \mathrm{~m}$ since neither the green spiny lobster nor the painted spiny lobster occurs in this range [54]. Living exclusively in mesophotic (water with low light penetration) reef ecosystems in the GARS, where mature adults make up more than $50 \%$ of the lobster stock, giant red spiny lobsters reach an average CL of $100.55 \pm 0.2855 \mathrm{~mm}$ and have a very high reproductive potential [6]. Their versatile feeding habits include a wide range of benthic and infaunal organisms such as crabs, soft crabs, and anomurans [4].

\subsection{Life Cycle}

Cruz et al. $[6,8]$ described the circulation and dispersal of larvae on the CSB during the planktonic stage, with subsequent recruitment, but due to ontogenetic vertical migration, it is still unknown how far from the parental stock the larvae travel. Briefly, by the end of the last phyllosoma stage (XI), the animals molt into pueruli. The pueruli become solitary juveniles (algal phase), then gregarious juveniles. They are recruited to the fishing grounds 27-33 months after hatching, depending on spatial and temporal factors (Figure 6). 


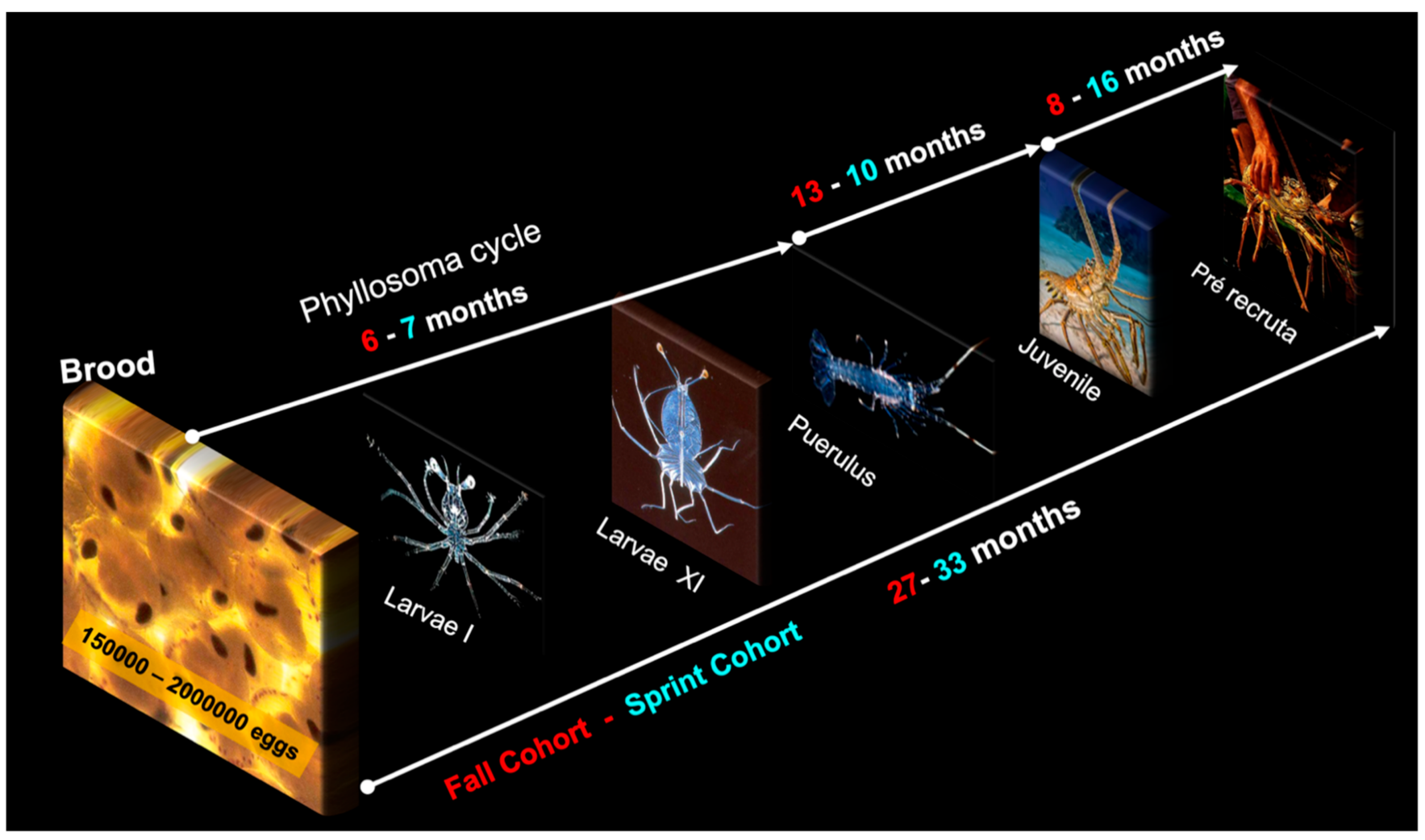

Figure 6. Summary of life cycle of Brazilian form of Panulirus argus (Latreille, 1804) showing evolution of a cohort from moment of hatching. Reproductive cycle is divided into four stages: spawning, larval recruitment to Brazilian coast, juvenile recruitment to nurseries, and recruitment to fishing grounds. Adapted from Cruz et al. [6].

Based on Cruz, et al. $[6,8,66]$, the present review contributes to current knowledge of the spiny lobster's life cycle and provides evidence of similar ecological behavior for Brazilian and Caribbean populations of P. argus, including the duration of the planktonic phyllosoma stage in the ocean, carapace length stratification, reproductive cycle, and preferred habitats during ontogenetic development.

Brazilian studies on scyllarids have focused on taxonomy, phylogeny, and distribution, with some details on the life cycle of P. antarcticus inhabiting mesophotic reef ecosystems. In the GARS, three females of and two male species of $P$. antarcticus were collected at depths between 76 and $101 \mathrm{~m}$ [67]. The females carried hard black spermatophores and had pleopods with long setae (Figure 7A), as observed in spiny lobster species [68]. Females carrying eggs with fresh spermatophores (Figure 7B) is evidence of repeated spawning without molting; that is, females can produce two or more broods separated by three or four weeks. In the Caribbean, female P. argus larger than $100 \mathrm{~mm}$ CL spawn at least twice, separated by three or four weeks $[69,70]$.

The metamorphosis of eggs into naupliosoma larvae was not observed for P. antarcticus or any other scyllarids [71]. Johnson et al. [72] estimated the length of larval life in Hawaiian waters to be approximately nine months, with 11 stages and a final phyllosoma size of $83 \mathrm{~mm}$ (TL). On isolated oceanic reefs over $220 \mathrm{~km}$ from continental Australia, Palero et al. [73] identified eleven larval stages in the plankton, measuring between 75 and $80 \mathrm{~mm}$ TL. These 'giant phyllosomata' are probably the largest decapod larvae reported so far (Figure 8). 


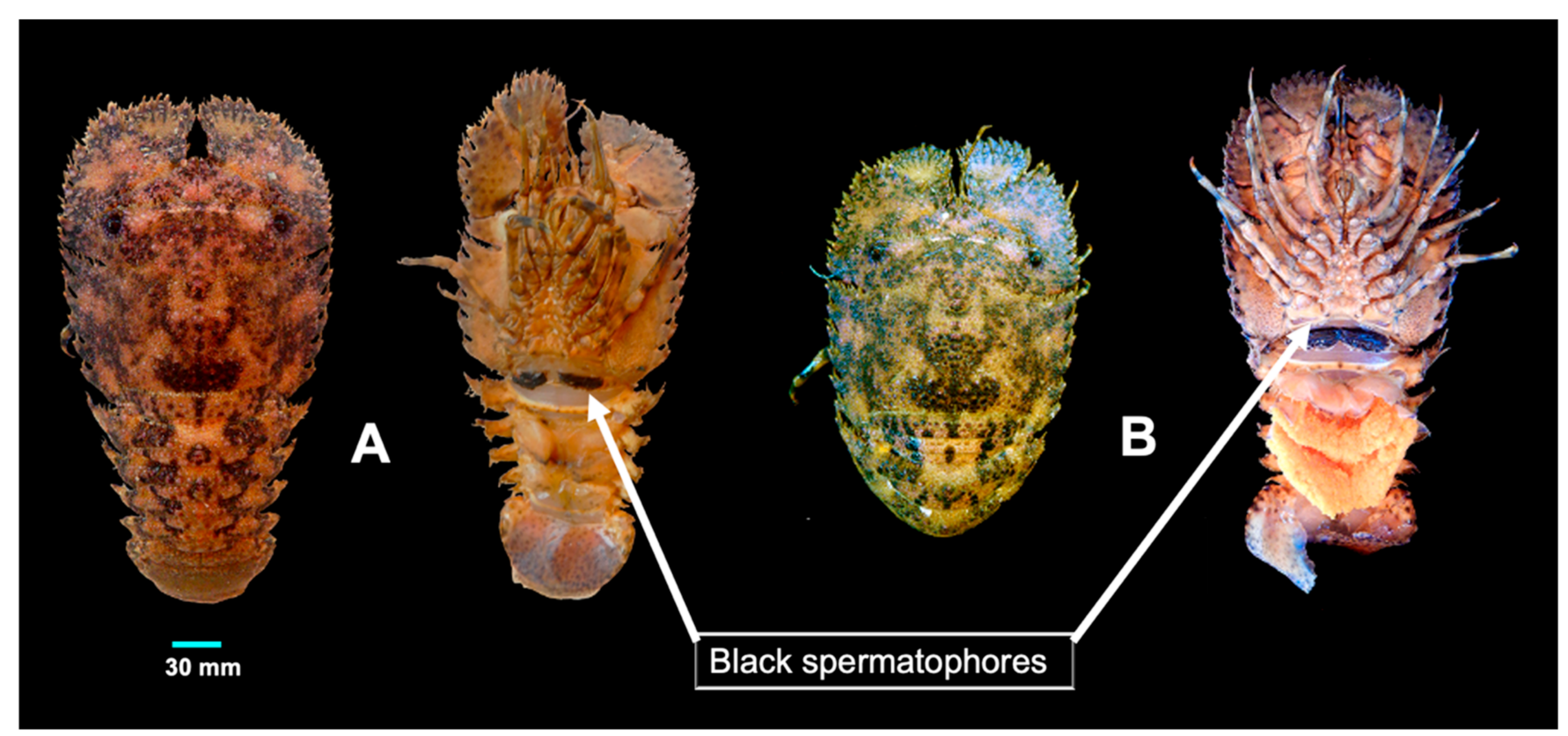

Figure 7. Dorsal and ventral view of two female Parribacus antarcticus (Lund, 1793). (A) Black spermatophores and pleopods with long setae. (B) Eggs concomitant with fresh spermatophores. Adapted from Cintra, et al. [67].

In NE, two transparent nistos measuring $24.64 \mathrm{~mm} \mathrm{CL} \mathrm{(46.51} \mathrm{mm} \mathrm{TL)} \mathrm{and} 26.62 \mathrm{~mm}$ CL (49.57 mm TL) (nistos are equivalent to panulirid pueruli) were collected off Flecheiras $\left(39^{\circ} 13.5^{\prime} \mathrm{W}, 3^{\circ} 14.5^{\prime} \mathrm{S}\right)$ in an area with extensive marine seaweed beds. Johnson, et al. [72] reported nistos in the wild to measure $20-21 \mathrm{~mm} \mathrm{CL}$. When captured, the body was transparent (except for the pigmented eyes) and depressed, with short, blade-shaped antennas. The lateral margin of the four antennas and the carapace were slightly serrated. The pleopods were highly developed and the shell was poorly calcified and devoid of spines.

Nistos look like adult P. antarcticus (Figure 8), but the duration of the stage is unknown. Individuals probably become solitary bottom dwellers before reaching their final habitat. No live juveniles of $P$. antarcticus were ever sampled. Nistos subsequently molt into juveniles. The spatial and temporal recruitment to the adult fishing grounds was not estimated.

Settlement patterns and larval distribution were not determined for this species, but current retroflection and stationary eddies (Figure 8) very likely cause the retention of phyllosomata near their hatching sites, ensuring larval recruitment to parental stock, as with palinurids and other scyllarids. On the other hand, larvae of P. antarcticus hatched in the GARS are trapped in this oceanic system by a cyclone-anticyclone system [8], suggesting this area is the main source of retention and supply of surviving larvae, thus of self-recruitment.

\subsection{Biological Controls}

Changes in the abundance of predators and food or shelter can strongly affect lobster population trends, and fisheries can alter ecosystem functioning and condition. The interaction between ecological factors and fisheries is complex and needs to be better understood to mitigate fluctuations in Brazilian lobster stocks.

However, further research on seasonal variations in local currents, current retroflection and ring formation is needed to clarify important aspects of larval transport, nistos settlement, and recruitment. 


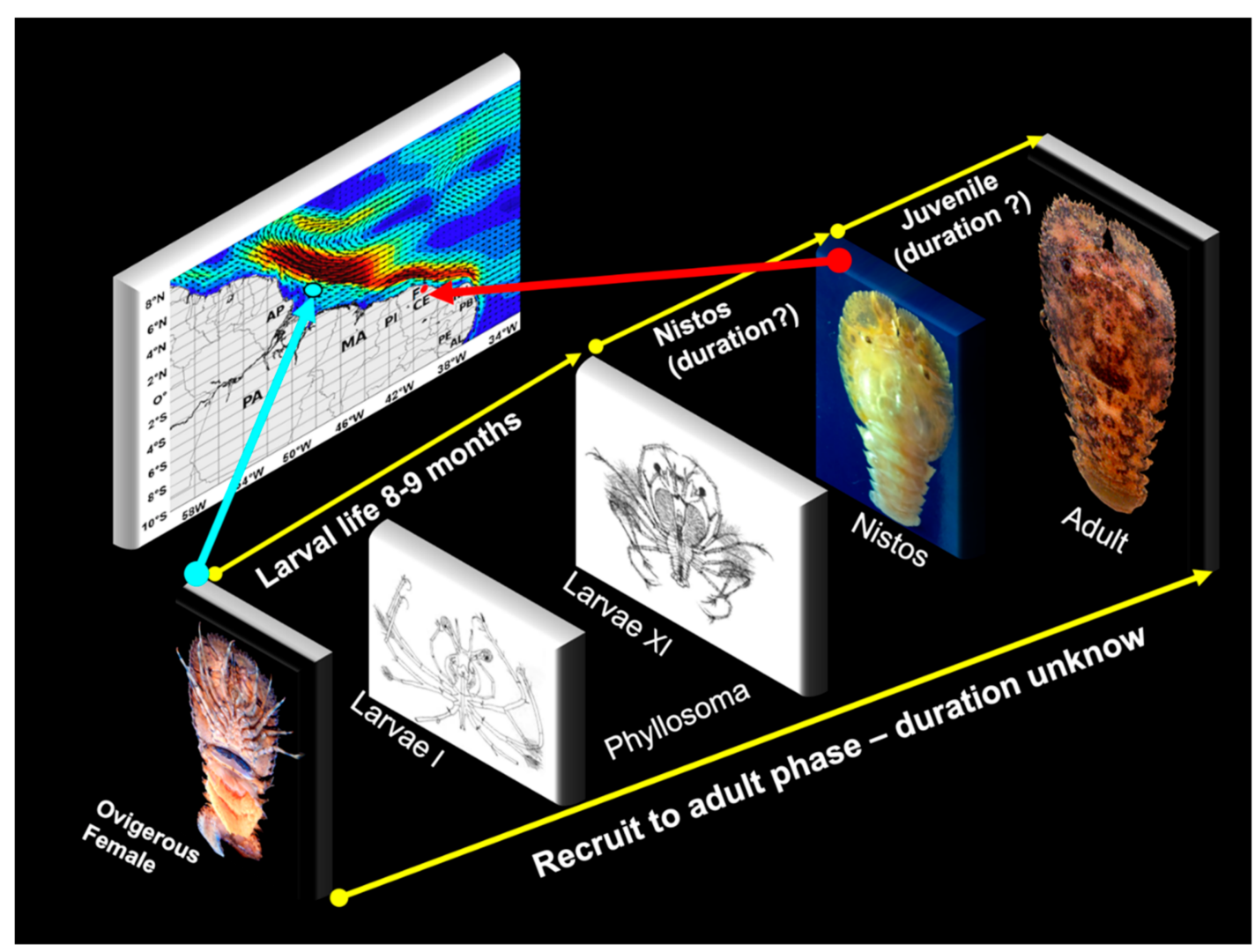

Figure 8. Theoretical scheme of life cycle of Parribacus antarcticus (Lund, 1793). Left: female carrying black spermatophores. Phyllosoma stages I to XI. Duration of the nistos and juvenile stages is unknown. Larvae and adults look alike. Map shows direction (arrow), intensity (color) and formation of retroflection eddies in North Brazil Current (Adapted from Cruz, et al. [8]). Light blue and red dot indicate locations in Great Amazon Reef System (GARS) and off Flecheiras (39 $13.5^{\prime}$ $\mathrm{W} 3^{\circ} 14.5^{\prime} \mathrm{S}$ ) where ovigerous females and nistos were sampled, respectively.

\subsubsection{Predators}

Lobsters in the benthic phase (postlarvae, juveniles, adults) are preyed on by demersal fish, sharks, octopi, and dolphins. Our review of lobster predators in the Caribbean was based on Buesa [74], Munro [75], Aitken [76], Kanciruk [77], Cruz et al. [78] and Cruz \& Phillips [79]. Juvenile lobsters were found in the stomachs of nurse sharks (Ginglymostoma cirratum) but many other fish species are known to prey on lobsters, including burrfishes, the Cuban snapper (Lutjanus cyanopterus), the grey snapper (Lutjanus griseus), the yellowtail snapper (Ocyurus chrysurus), triggerfishes (Balistidae), the red grouper (Epinephelus morio), and the old wife (Enoplosus armatus).

The lane snapper (Lutjanus synagris) and the spotted moray (Gymnothorax moringa) all eat juvenile lobsters. Occasionally, different types of sharks, turtles and octopi consume lobsters. Octopi are major lobster predators in Western Australia [80]. Their presence along the Brazilian coast suggests they prey on lobsters in this region as well, but little is known about their abundance.

As shown by Santana, et al. [15], lobster trap by-catch in NE consists primarily of snappers and grunts $(60 \%)$, including species that prey on juvenile or mature lobsters (lutjanids, serranids, balistids, octopi).

The red snapper (L. purpureus Poey, 1866) occurs in the GARS and NE at depths between 25 and $160 \mathrm{~m}$, where it was an important commercial fishing resource since 1961 [81]. Ivo \& Hanson [82] hypothesized a migratory spawning pattern for the red snapper, with adults migrating to oceanic banks in NE (Ceará, Rocas Atoll, Caiçara) and juveniles recruiting to the nursery area close to the Amazon River mouth. The species feeds mostly on fish (89\%), followed by crustaceans (8-10\%, including lobsters) and a variety 
of benthic invertebrates (1-3\%, including holothurians, mollusks, squids, annelids, and crustacean larvae) [83]. Other authors have included foraminifera, coelenterates, sponges, and encrusted bryozoans in the diet [84].

Dolphins (Delphinidae) are abundant on the CSB, with 21 species represented [85], all of which are carnivorous. Some prefer crustaceans (e.g., lobsters) [75], others eat a variety of shrimp, crabs, octopi, and cuttlefish. Dolphins are sighted both inshore and at high sea, including many lobster habitats. However, based on currently available information, dolphins cannot be confirmed to be key lobster predators.

According to Gupta, et al. [86], the little tunny (Euthynnus affinis Cantor, 1849) is an opportunistic pelagic predator of crustacean larvae, including scyllarid phyllosomata and spiny lobster pueruli $(0.78 \%)$. In some cases, as observed on the coast of India (Cuddalore), they prey on larvae in the coastal zone, prior to settlement. Likewise, a preliminary analysis of the stomach contents of the skipjack tuna (Katsuwonus pelamis Linnaeus, 1758) revealed phyllosomata (pers. comm. by Raul Cruz).

Nine species of whales were sighted along the CSB [85]. Most feed on planktonic organisms, especially krill (Euphausia superba Dana, 1850), but the diet may also include small fish, copepods and some species of shrimp [87]. Available evidence supports the hypothesis that planktonic lobster larvae are ingested by whales, but the scarcity of information on the distribution of phyllosomata in Brazilian waters prevented a deeper understanding of this prey-predator relationship.

\subsubsection{Feeding Behavior}

Lobsters are opportunistic carnivores, preying on a wide variety of benthic invertebrates such as crustaceans, bivalves, annelids, echinoderms and gastropods. To a lesser degree, lobsters eat stomatopods, fish, polychaetes, ophiuroids, anemones, polyplacophores and asteroids, incidentally ingesting isopods, sipunculans, amphipods, and fragments of vegetation [88,89]. According to Herrera et al. [88], in response to ecological requirements spiny lobster populations migrate within the wider Caribbean in search of coarser sediments and macroinfauna (organisms $>5 \mathrm{~mm}$ ) with higher biomass density.

To minimize exposure to predation, large lobsters and scyllarids forage mainly at night and return to their protective shelter before dawn [79]. However, the feeding strategy of lobsters in deep waters is still unknown.

The abundance of oceanic phyllosomata $[90,91]$ coincides with the relative abundance of gelatinous zooplankton, suggesting phyllosomata prey on this source [92]. The presence of jellyfish, ctenophores and salpids in the digestive glands of phyllosomata $[93,94]$ indicates larvae are carnivorous predators at this stage.

In the last phyllosoma stage, when preparing to metamorphose into transparent nektonic pueruli, larvae stop feeding and subsist on stored energy [95]. In this study, we identified a nisto (transparent stage) of P. antarcticus very similar to the nisto of Petrarctus brevicornis (Holthuis, 1946) described by Wakabayashi, et al. [96]. In the post-puerulus stage, bottom-dwelling juveniles feed on copepods, amphipods, isopods, holothurians, and foraminifera [97].

\subsubsection{Benthic Habitats and Length Assessment}

Lobsters occur in benthic habitats from tide pools to the deep sea (4000 m) (see Table 1), but the large spiny lobsters exploited by the fishing industry are found at depths between 1 and $110 \mathrm{~m}$ [66]. Coral communities on the CSB differ very much from those in the wider Caribbean, in part due to heavy silting from the coast.

Covering $9500 \mathrm{~km}^{2}$, the GARS features extensive reef platforms, reef walls, rhodoliths beds, sponge bottoms [98], and some 25 species of red algae [5] which serve as refuges and feeding grounds for benthic invertebrates such as lobsters and demersal fish. The great diversity of sponges (61 known species) in the GARS $[99,100]$ increases the availability of shelters for lobsters at different stages of development and, consequently, ensures local 
abundance. However, as lobsters grow, the protection from predators provided by fractal refuges is rapidly lost [101].

In NE, pueruli dwell among red algae clones, such as Gracilaria sp. and Amansia sp., and to a lesser extent among Cryptonemia sp. [102]. As in the wider Caribbean, algae beds attract a wide array of small invertebrates (mollusks and crustaceans) which serve as food sources.

The average size, geographical distribution and habitat depth of spiny lobsters follow a stratified pattern, as shown by Cruz et al. [6]. For example, in deeper waters (50-100 m) large individuals are predominant (80\% in the range $90-180 \mathrm{~mm}$ CL; average $100.55 \pm 0.2855 \mathrm{~mm} C L$ (average $\pm 95 \%$ confidence interval)) (senile individuals are particularly abundant in the GARS) and egg production is very high (76\%). In this habitat, the red spiny lobster is ecologically predominant due to its large size, versatile feeding habits, and reliance of rhodoliths for shelter. In NE, smaller size is correlated with smaller depth: $63.85 \pm 0.324 \mathrm{~mm} \mathrm{CL}$ at 3-5 m depth, 72.74 $\pm 0.695 \mathrm{~mm} \mathrm{CL}$ at 10-20 $\mathrm{m}$ depth, and $85.61 \pm 0.5889 \mathrm{~mm}$ CL at 30-40 $\mathrm{m}$ depth.

\subsubsection{Commercial Fisheries}

Brazilian red spiny lobster stocks were heavily exploited since the 1960s, but landings fluctuated greatly over time. When landings surpassed the upper limit $(6480 \mathrm{t})$ of the $95 \%$ confidence interval of the maximum sustainable yield (5570 t), production declined abruptly between $27 \%$ and $46 \%$ (Figure 9 ).

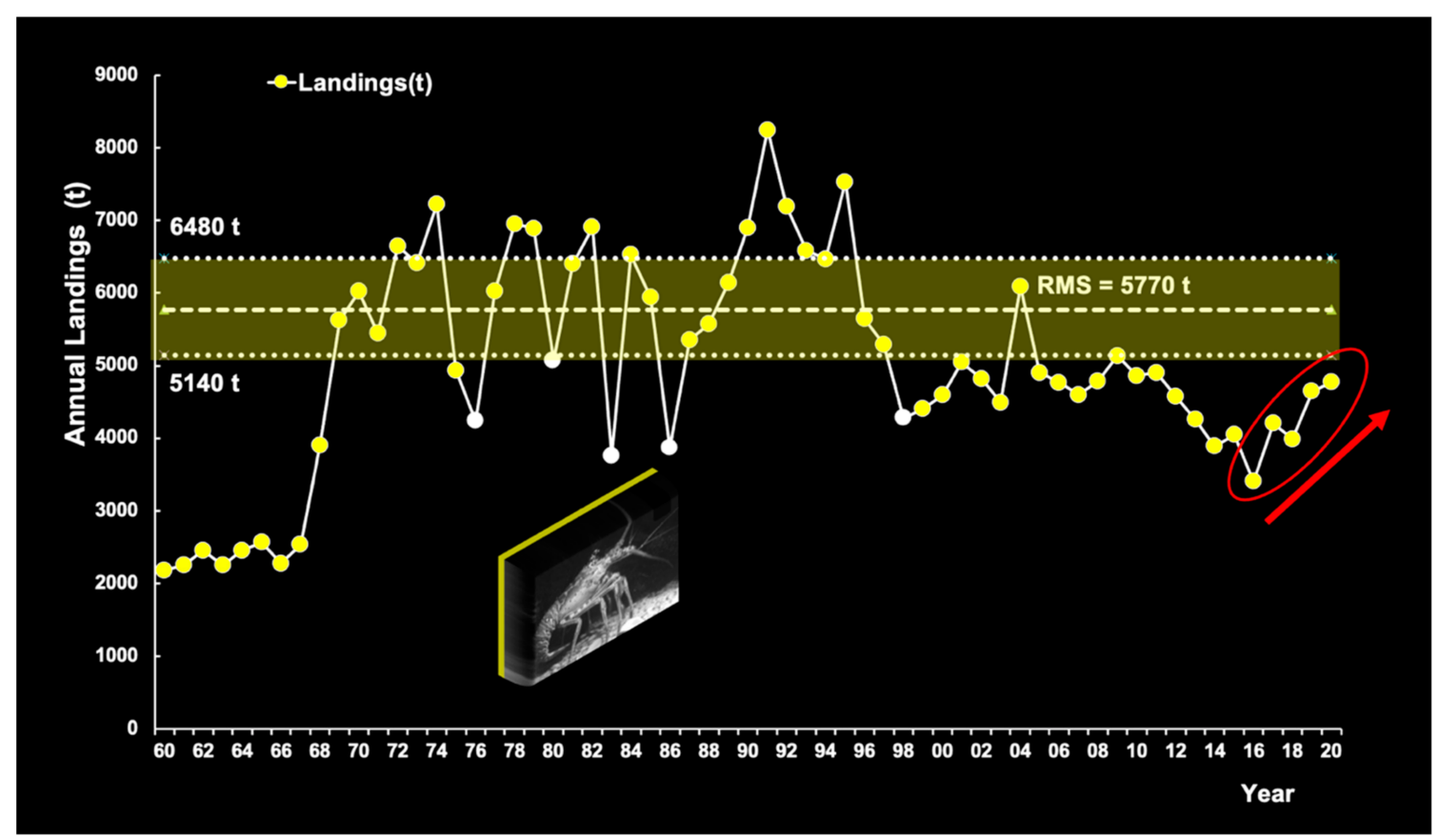

Figure 9. Fluctuations in annual landings of Brazilian form of Panulirus argus (Latreille, 1804), showing periods of overfishing (white dots) and reductions. Dotted horizontal line represents maximum sustainable yield (MSY = rk $/ 4$ ). Shaded area is $95 \%$ confidence interval (5140-6480 t). Oval circle and red line show an increase in landings since 2016. Adapted from Cruz et al. [17].

As reported by Cruz et al. [6], in years with no closed season on lobsters (2000-2006), the effort exerted in the 6-month period between November and April represented 40-49\% of the annual total. It would therefore seem that the average fishing effort in 2012-2020 was reduced by approx. $45 \%$ during the 6-month closed season, corresponding roughly to a $30 \%$ decrease in relative fishing pressure (F/Fmsy). Cruz et al. $[6,13]$ observed that the closed season (November to April) currently protects spiny lobsters during sensitive stages of the life cycle: spawning, recruitment to nursery areas and recruitment to fishing grounds at an average size of $76.5 \mathrm{~mm}$ CL. These results are very consistent: in 2009 (number of 
individuals, $n=730,262)$ and $2010(n=294,374)$, the percentage of undersized red lobsters (legal minimum size: $75 \mathrm{~mm} \mathrm{CL}$ ) was $27.4 \%$ and $29.7 \%$, respectively, but in $2018(n=3810)$ it dropped to $0.70 \%$. Likewise, a lobster sampling conducted at a local processing plant in $2018(n=862)$ yielded a relatively low percentage $(3.7 \%)$.

The red lobster and the green lobster (Figure 10) are captured with the same artisanal fishing gear. Therefore, fluctuations in landings are similar for the two species. The management strategy and the duration (six months) and period of the closed season are also the same, but the minimum legal size is different $(65 \mathrm{~mm}$ CL for green lobsters; $75 \mathrm{~mm}$ CL for red lobsters). No significant association was observed between the time series of landings of P. laevicauda and the Brazilian form of P. argus between 1965 and 1994 [17], probably due to variations in recruitment and oceanographic-environmental factors. Further studies are needed to clarify the interaction between environmental factors and the complex life cycle of these two species of spiny lobster, as well as the effects of spawning stocks on the level of puerulus settlement.

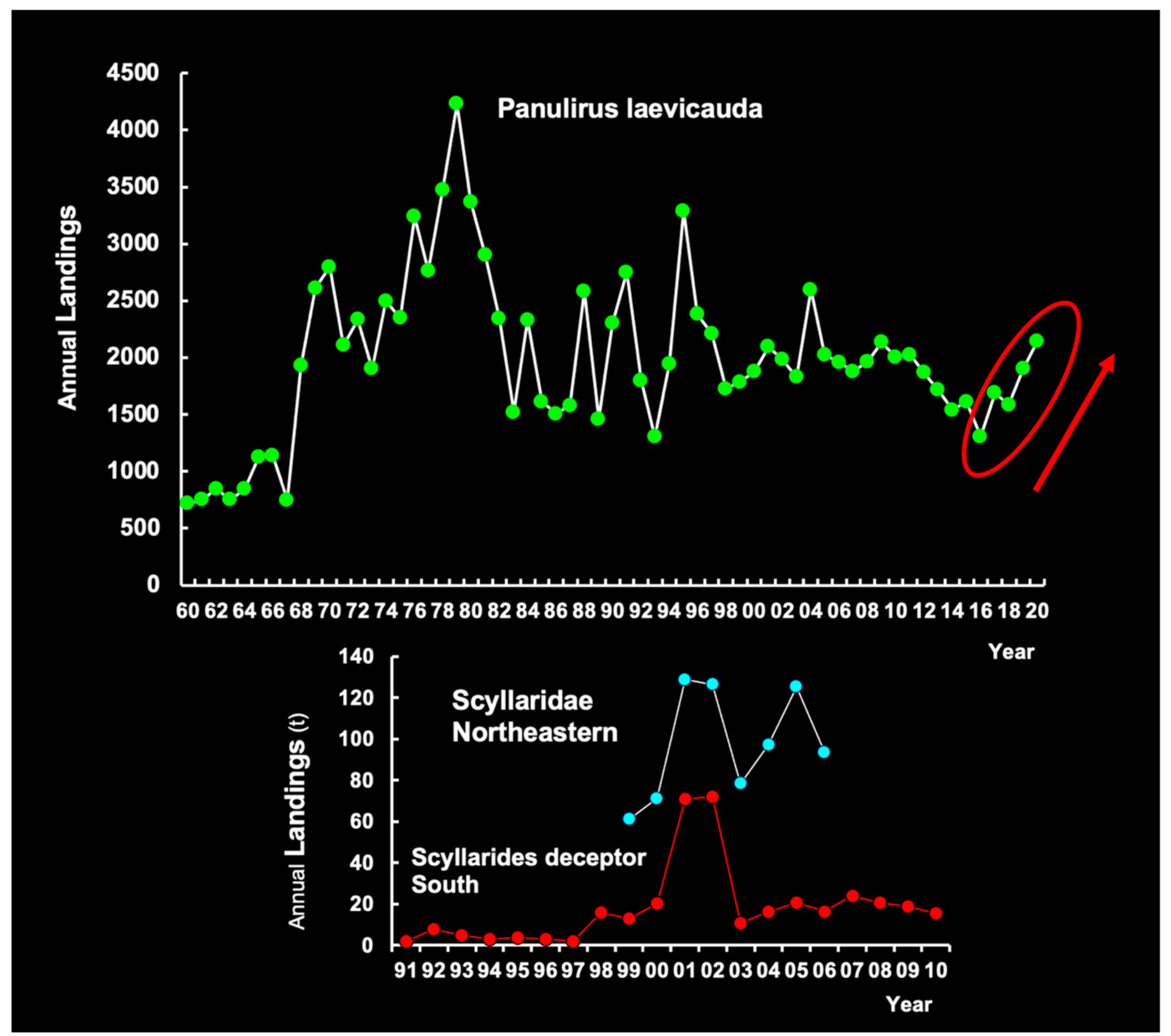

Figure 10. Fluctuations in annual green lobster landings (Panulirus laevicauda Latreille, 1817). Oval circle and red line show an increase in landings since 2016. Lower graph shows landings of several species of Scyllaridae (Scyllarides brasiliensis Rathbun, 1906; Scyllarides delfosi Holthuis, 1960 and Parribacus antarcticus (Lund, 1793) in Northeast, and landings of Scyllarides deceptor Holthuis, 1963 in the South. Adapted from Cruz et al. [17].

Slipper lobster landings were always very limited in the western Atlantic (Figure 10). In NE, total annual landings amounted to 60-127 $t$ (average $98 \mathrm{t}$ ) in the period 1999-2006. The landings of $S$. deceptor alone ranged between $1.0 \mathrm{t}$ and $24.0 \mathrm{t}$, although peaks of $72 \mathrm{t}$ occurred in 2000 and 2001. The slipper lobster S. deceptor is captured as pink shrimp trawler by-catch in Southern Brazil [103]. The slipper lobster stocks on the CSB were 
not fully assessed and the impact of fluctuations in fishing effort, catch, and stock size is virtually unknown.

\subsection{Predator-Prey Interactions}

The red snapper Lutjanus purpureus Poey, 1866 (predator) and red spiny lobster (prey) coexist in the GARS where they represent the two most valuable fishing resources. Both species occupy niches in contact with the substrate and feed at night, making the probability of predator-prey interactions very high. Lobsters carry their bright orange eggs on the underside until they turn brown and hatch. The carnivorous larval stage in Brazilian oceanic waters lasts from 6 to 7 months, until the animals settle in shallow coastal areas among vegetation and algae beds [6]. On the other hand, red snapper eggs float freely in oceanic areas and once hatched, the larvae remain pelagic for 30 days. At approximately 8 months, the juveniles settle in coastal habitats [104]. It is not yet clear why this settlement is so strongly associated with structured habitats, but it may be related to the need for shelter from predators.

Red spiny lobster phyllosomata are opportunistic predators feeding on a variety of prey, depending on the stage. In the early stages, soft prey (fish larvae and gelatinous zooplankton) is preferred, but in the later stages the diet consists of larger prey such as shrimp, copepods, and amphipods [105]. Red snapper larvae are known to feed on crustacean larvae, but to our knowledge no study was conducted identifying the species consumed. In pelagic fish larvae, mouth size is the most important factor determining prey size [106]; for example, in the stage between hatching and 5 days of age, Lutjanus argentimaculatus (Forsskål, 1775) start by eating nauplii measuring 0.10-0.15 mm TL and end by easting copepods measuring 0.20-0.50 mm TL [107]. Planktonic red snapper larvae in their early stages do not prey on stage I phyllosomata due to their large size (1.55-1.60 mm TL) [91].

Cross-correlations were calculated between the red snapper and the red lobster and the lagged detrended production $(\mathrm{t})$ series. A significant negative correlation $(n=34$ years, $\mathrm{r}=-0.45)$ was found between snapper production and red lobster production, with a 3-year lag (Figure 11). The present approach is exploratory. Our results may be explained by predator-prey (snapperlobster) interactions, but at this point it is not possible to estimate to what extent other species compete for the same habitat and food resources.

On the other hand, red spiny lobster recruitment to fishing grounds happens with a lag of three years. That could mean that peaks in lobster production are the effect of high levels of recruitment $[6,108]$ or of a decrease in predation risk. We hypothesize overfishing and low levels of recruitment were responsible for red snapper landings below the maximum sustainable yield following the periods 1970-1972, 1981-1982, and 1990-1991.

The compounded impact of fishing and trophic interactions on Brazilian lobster stocks is not well understood, but it is possible at this point to put together a simplified theoretical scheme (Figure 12) considering the biological control discussed above.

Lobsters are prey to a range of demersal predators, to fishermen employing efficient methods, and to pelagic fish and mammals feeding on plankton (including phyllosomata, nistos, and pueruli), but the effect of the latter on larval recruitment is unknown. Lobsters appear to prefer other decapods and mollusks. More study on the role of these species in the food chain is needed to identify temporal tendencies of abundance and larval recruitment.

In this review, we took a critical look at the claim that changes in key predator abundance can strongly impact prey abundance (lobsters). At the primary level, reciprocal predator-prey effects are those capable of altering the abundance of a population through the food chain top-down (the very large drive the very small) [7]. 


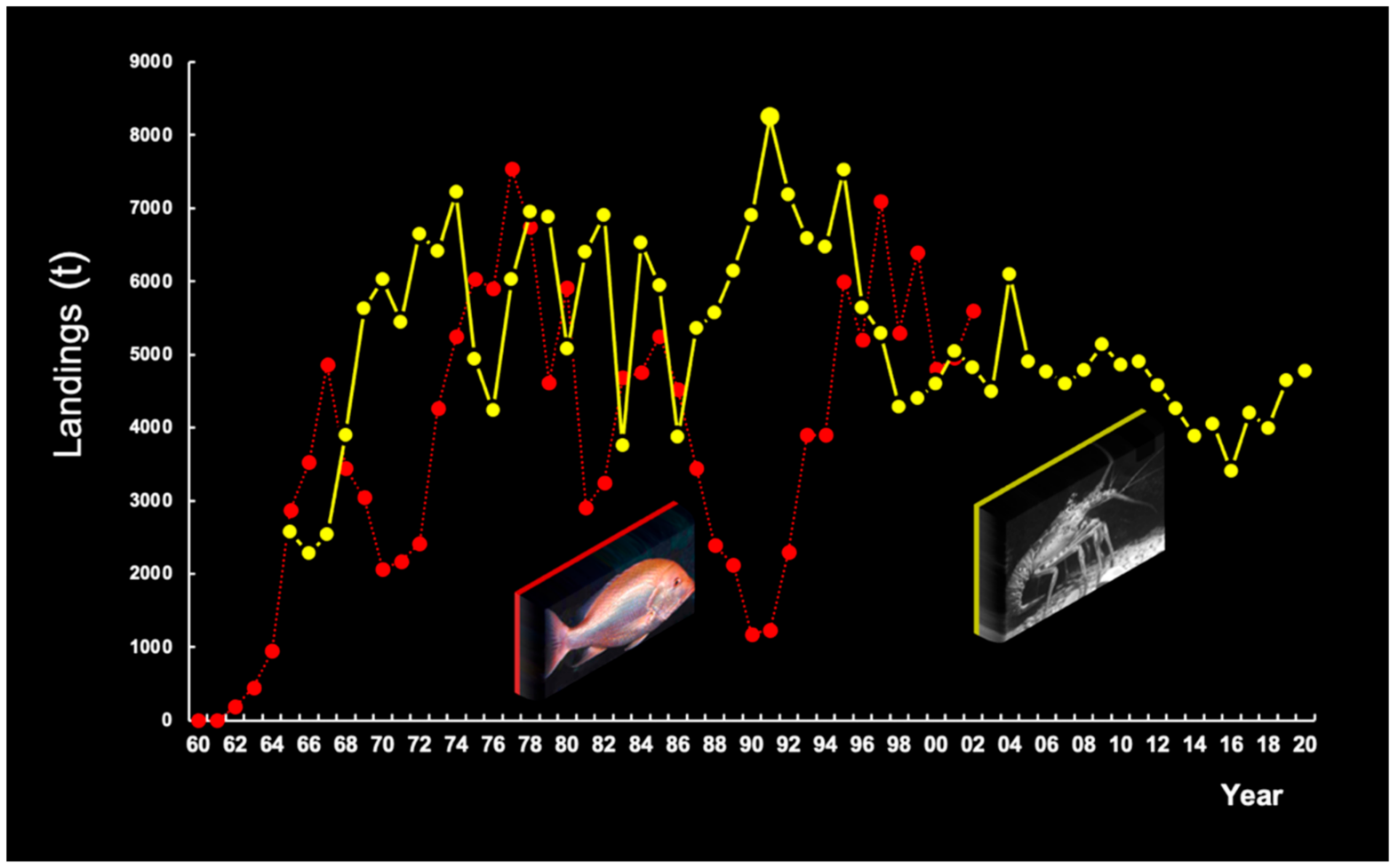

Figure 11. Annual landings of Brazilian form of Panulirus argus (Latreille, 1804) and red snapper (Lutjanus purpureus Poey, 1866) with a 3-year lag in Great Amazon Reef System (GARS) and in Northeast (NE).

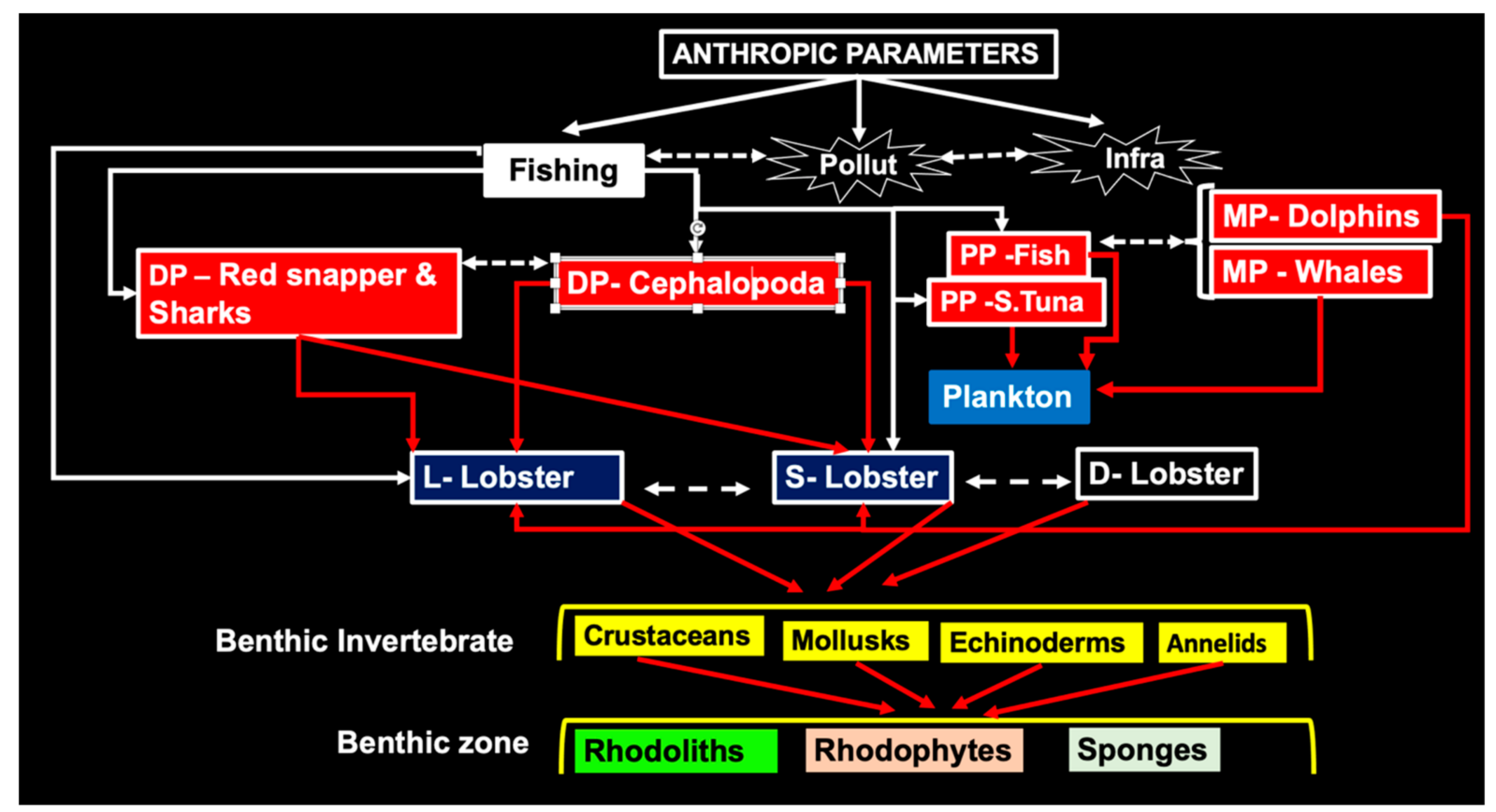

Figure 12. Theoretical scheme showing ecosystem and trophic interactions between lobsters, potential predators (box and line in red) and fisheries. $\mathrm{DP}=$ demersal predators. $\mathrm{P}=$ predators. $\mathrm{PP}=$ pelagic predators $(\mathrm{S}$. tuna $=$ small tuna). $\mathrm{MP}=$ mammal predators (dolphins and whales). $\mathrm{L}=$ spiny lobster; $\mathrm{S}=$ slipper lobster. $\mathrm{D}=$ deep-sea lobster (without information on its ecology). Plankton $=$ phyllosomata. Benthic invertebrates $=$ main lobster diet (benthic and infaunal organisms). Benthic zone = ecological region at lowest level of a body of water. Rhodoliths = composed of several species of calcareous algae. Rhodophytes $=$ red algae. Sponges $=$ increases availability of shelters for different species and juveniles. Pollut $=$ pollution. Infra $=$ infrastructure developments. Dotted arrows $=$ probable interactions . 
The scheme in Figure 13 shows how fisheries may be impacted by low abundance of predators (red snappers) and high abundance of prey (lobsters) (Figure 13A). Response to exploitation (Figure 13B) shows that the decreasing abundance of demersal predators (reduced predation) is associated with increased lobster landings.

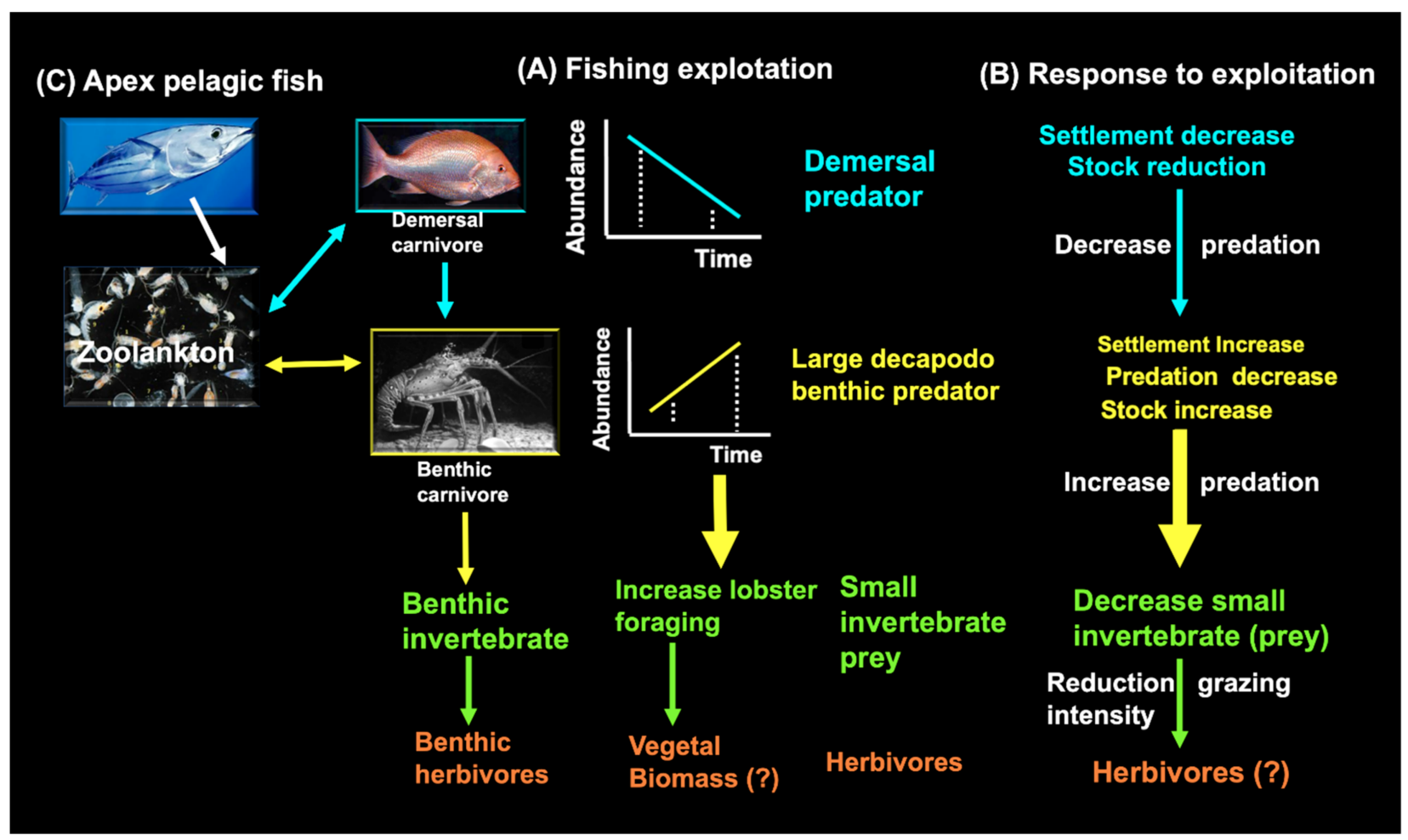

Figure 13. Theoretical model of top-down control. (A) Fishing exploitation of top predators (demersal carnivore) and red spiny lobster (benthic keystone) on continental shelf of Brazil (CSB). Decreasing production (abundance) of demersal predator (snapper) leads to increased prey abundance (see Figure 11). (B) Response to exploitation. The decreasing abundance of the demersal predator populations leads to reduce predation on the prey (red spiny lobster), which in turn leads to an increase in abundance and increased predation in small invertebrate (prey). (C) Apex pelagic fish. The increase of predation on zooplankton, leads to a decrease the abundance of larval recruitment. Thick arrows represent strong trophic interactions; thin arrows represent weak interactions.

As explained above, no predator-prey interactions exist between red snapper larvae and lobster phyllosomata. Animal species mostly interact through predation and competition [109], whether directly or indirectly. It is therefore reasonable to assume that increased predation on zooplankton by pelagic apex predators (Figure 13C) like skipjack (K. pelamis) that feed primarily upon small schooling fishes, mollusks, eggs, and crustacean larvae and pueruli in the zooplankton, leads to a decrease in zooplankton biomass, reducing the abundance of certain types of fish larvae, eggs, and phyllosomata.

Unfortunately, the variation in the biomass of benthic invertebrates and herbivores over time is unknown. But, as pointed out by Cury et al. [7], there is no need to measure all parameters to visualize the overall dynamics.

\section{Conclusions}

This review lists 24 lobster species distributed along the continental shelf of Brazil, from shallow to deep waters (Palinuridae 25\%, Scyllaridae 29\%, Nephropidae 25\%, Polychelidae 17\%, Enoplometopidae 4\%). The maximum total size (MTL) of these species ranged from 30 to $620 \mathrm{~mm}$.

The collected evidence supports the notion that the red spiny lobster (the Brazilian form of P. argus) is the largest and-due to its broad distribution-most important crus- 
tacean apex predator in the benthic community. The giant lobster is the most abundant palinurid in Brazil and the keystone of the benthic community. Changes in red spiny lobster abundance, for example, caused by anthropogenic impacts, can potentially compromise predator-prey interactions and the food-habitats of other species.

We know several species of slipper lobster (Scyllaridae) caught as associated fauna in spiny lobster traps are traded on the market, despite the lack of life-cycle information, stock assessments, or resource management. Deep-sea lobsters (Nephropidae and Polychelidae) have no commercial potential, and little is known about their bioecology.

Our review includes general aspects of the life cycle of the slipper lobster P. antarcticus and some new evidence (females carrying eggs with fresh spermatophores, indicating the ability to produce at least two broods in the same season). In addition, the capture of two nistos near the shore suggests slipper lobster larvae disperse in the ocean like Panulirus and settle in shallow waters.

We also provide evidence that changes in snapper abundance (predator) may have a strong effect on lobster abundance (prey). At this level, reciprocal predator-prey effects can change the abundance or productivity of a population through the food chain (topdown control).

Author Contributions: R.C. designed research, conceptualization, analyzed the data, original figures preparation, and wrote the manuscript; M.T.T. conducted the literature review, table preparation and interpretation, and review the manuscript; J.V.M.S. and I.H.A.C. collection, conservation and analyzed of biological material in different regions of Brazil (Great Amazon Reef System and the Northeastern). All authors have read and agreed to the published version of the manuscript.

Funding: This study was supported by Fundação Cearense de Apoio ao Desenvolvimento Científico e Tecnológico (FUNCAP) and Sindicato das Indústrias de Frio e Pesca do Ceará, Brazil (SINDFRIO).

Institutional Review Board Statement: Not applicable.

Informed Consent Statement: Not applicable.

Data Availability Statement: Not applicable.

Acknowledgments: The authors would like to thank FUNCAP (Fundação Cearense de Apoio ao Desenvolvimento Científico e Tecnológico, Ceará, Brazil), SECITECE (Secretaria da Ciência, Tecnologia e Educação Superior), SEDET (Secretaria de Desenvolvimento Econômico e Trabalho, Ceará, Brazil), IFCE (Instituto Federal de Educação, Ciências e Tecnologia do Ceará, Campus Acaraú), ISARH (Instituto Socioambiental e dos Recursos Hídricos), and UFRA (Universidade Federal Rural da Amazônia) for logistic support. Gratitude is extended to the exporters and producers affiliated with SINDFRIO (Sindicato das Indústrias de Frio e Pesca do Ceará, Brazil). The autors are also grateful to SAP/MAPA (Departamento de Registro e Monitoramento de Aquicultura e Pesca). We also like to extend our special thanks to anonymous referees and academy editor. Finally, many thanks to Tin-Yam Chan/Muséum national d'Histoire Naturelle, Joseph Poupin/École Navale, scientifique du Muséum de Paris, and Darryl L. Felder/University of Louisiana at Lafayette, LA, USA, for allowing us to reproduce photographs of lobster species.

Conflicts of Interest: The authors declare no conflict of interest.

\section{Appendix A. Provides a List of the Species Surveyed}

List of marine lobsters by family on the continental shelf of Brazil.

Palinuridae Latreille, 1802 (spiny lobsters)

1. Brazilian form of Panulirus argus (Latreille, 1804).

2. Panulirus laevicauda (Latreille, 1817).

3. Panulirus echinatus Smith, 1869.

4. Palinustus truncatus A. Milne-Edwards, 1880.

5. Justitia longimanus (H. Milne Edwards, 1837).

6. Palinurellus gundlachi von Martens, 1878. 


Scyllaridae Latreille, 1825 (slipper lobsters)
7. Scyllarides delfosi Holthuis, 1960.
8. Scyllarides brasiliensis Rathbun, 1906.
9. Scyllarides deceptor Holthuis, 1963.
10. Scyllarus chacei Holthuis, 1960.
11. Scyllarus depressus (S. I. Smith, 1881).
12. Scyllarus americanus (S. I. Smith, 1869).
13. Parribacus antarcticus (Lund, 1793).
Nephropidae Dana, 1852 (clawed lobsters)
Acanthacaris caeca (A. Milne-Edwards, 1881).
15. Nephropsis aculeata Smith, 1881.
16. Nephropsis rosea Bate, 1888.
Nephropsis agassizii A. Milne-Edwards, 1880.
18. Nephropsis neglecta Holthuis, 1974.
19. Metanephrops rubellus (Moreira, 1903).
Wood-Mason, 1874 (blind lobsters, primitive decapods)
20. Stereomastis sculpta (Smith, 1880).
21. Polycheles typhlops C. Heller, 1862.
22. Pentacheles laevis Bate, 1878.
Pentacheles validus A, Milne Edwards, 1880.
Enoplometopidae de Saint Laurent, 1988.
24. Enoplometopus antillensis Lütken, 1865.

\section{Appendix B.}

List of the source photographs by authors.

\begin{tabular}{cc}
\hline List of Species (Appendix A) & Authors (Photo Credits) \\
\hline $1,2,3,7,8$ & Cruz et al. [54]. \\
$4,13,14,16$ & Silva et al. [55]. \\
5,6 & Cruz et al. [56]. \\
9 & Tavares et al. [36]. \\
10 & Silva et al. [47]. \\
11 & Puciarelly \& Rego [57]. \\
12 & No restrictions \\
15,16 & Photo (live color) Poupin J. in Legal \& Poupin [58]. \\
17,18 & Photo (live color) Alves-Junior et al. [48]. \\
19 & Photo (live color) Scarabino, F. [59]. \\
20 & Photo (live color) Felder, D. [60]. \\
21,22 & Photo (live color) Tin-Yam Chan/Muséum national \\
23 & d'Histoire naturelle" [24] \\
24 & Ahyong \& Shane [61]. \\
& Holthuis [3]. \\
\hline List of Species (Appendix A) & \\
\hline $4,14,18,19,9,25$ & Line Drawing Credits \\
$14,20,21$ & Holthuis [3]. \\
12 & Cruz et al. [56]. \\
\hline
\end{tabular}

\section{References}

1. Alencar, C.A.G.; Tavares, L.S.; Cintra, I.H.A. Current State of lobster exports in Brazil Research. Soc. Dev. 2020, 9, e312985804. [CrossRef]

2. $\quad$ Phillips, B.F.; Cobb, J.S.; George, C.R.W. General biology. In The Biology and Management of Lobsters; Cobb, J.S., Phillips, B.F., Eds.; Academic Press: New York, NY, USA, 1980; Volume 1, pp. 1-82.

3. Holthuis, L.B. Marine lobsters of the world. An annotated and illustrated catalogue of marine lobsters known to date. In $F A O$ Species Catalogue; FAO: Italy, Rome, 1991; Volume 13, pp. 1-292. 
4. Silva, K.C.A.; Cintra, I.H.A.; Ramos-Porto, M.; Viana, G.F.S.; Abrunhosa, F.A.; Cruz, R. Update on crustaceans known from the amazonian continental shelf and adjacent oceanic areas. Crustaceana 2020, 93, 687-701. [CrossRef]

5. Silva, K.C.A.; Cruz, R.; Cintra, I.H.A.; Abrunhosa, F.A. Structure and diversity of the lobster community on the Amazon continental shelf. Crustaceana 2013, 86, 1084-1102. [CrossRef]

6. Cruz, R.; Borda, C.A.; Santana, J.V.M.; Barreto, C.G.; Paiva, B.P.; Gaeta, J.C.; Torres, M.T.; Silva, J.L.S.; Cintra, I.H.A. Life cycle and connectivity of the spiny lobster, Panulirus spp.: Case studies from brazil and the wider caribbean (decapoda, achelata). Crustaceana 2021, 94, 603-645. [CrossRef]

7. Cury, P.; Shannon, L.; Shin, Y.J. The functioning of marine ecosystems: A fisheries perspective. In Responsible Fisheries in the Marine Ecosystem; Sinclair, M., Valdimarsson, G., Eds.; FAO: Italy, Rome; CABI Publishing: Wallingford, UK, 2003; pp. $103-123$.

8. Cruz, R.; Teixeira, C.E.; Menezes, M.O.B.; Santana, J.V.M.; Neto, T.M.; Gaeta, J.C.; Freitas, P.P.; Silva, K.C.A.; Cinbtra, I.H.A. Large-scale oceanic circulation and larval recruitment of the spiny lobster Panulirus argus (Latreille, 1804). Crustaceana 2015, 88, 298-323. [CrossRef]

9. Rebelo-Neto, J.E. Considerações sobre a pescaria do lagostim (Metanephrops rubellus) na região sudeste/sul do Brasil. CEPSULDocumentos Técnicos 1986, 10, 1-33.

10. Worm, B.; Barbier, E.B.; Beaumont, N.; Duffy, J.E.; Folke, C.; Halpern, B.S.; Jackson, J.B.C.; Lotze, H.K.; Micheli, F.; Palumbi, S.R.; et al. Impacts of Biodiversity Loss on Ocean Ecosystem Services. Science 2006, 314, 787-790. [CrossRef]

11. Wineland, S.M.; Kistner, E.J.; Joern, A. Non-consumptive interactions between grasshoppers (Orthoptera: Acrididae). And wolf spiders (Lycosidae) produce trophic cascades in an old-field ecosystem. J. Orthoptera Res. 2015, 24, 41-46. [CrossRef]

12. Boudreau, S.A.; Worm, B. Ecological role of large benthic decapods in marine ecosystems: A review. Mar. Ecol. Prog. Ser. 2012, 469, 195-213. [CrossRef]

13. Cruz, R.; Santana, J.V.M.; Barreto, C.G.; Borda, C.A.; Torres, M.T.; Gaeta, J.C.; Silva, J.L.S.; Saraiva, S.Z.R.; Salazar, I.O.; Cintra, I.H.A. Towards the rebuilding of spiny lobster stocks in Brazil: A review. Crustaceana 2020, 93, 957-983. [CrossRef]

14. Fonteles-Filho, A.A. The state of the lobster fishery in northeast Brazil. In Spiny Lobster Management; Phillips, B.F., Kittaka, J., Eds.; Blackwell: Oxford, UK, 2000; pp. 121-134.

15. Santana, J.V.M.; Neves, S.D.S.; Saraiva, S.Z.R.; Adams, C.; Cruz, R. Current Management and externalities in lobster fisheries exploitation on the continental shelf of Ceará, Brazil. Arq. Ciên. Mar. 2015, 48, 5-18.

16. Nascimento, R.C. Impactos Sócio-Ambientais de Marambaias Para a Pesca da Lagosta: O Caso de Ponta Grossa Icapuí-Ce. Tese Mestrado, Universidade Federal do Ceará, Fortaleza, Brazil, 2006; 86p.

17. Cruz, R.; Silva, K.C.A.; Neves, S.D.S.; Cintra, I.H.A. Impact of lobster size on catches and prediction of commercial spiny lobster landings in Brazil. Crustaceana 2013, 86, 1274-1290. [CrossRef]

18. Moura, R.L.; Amado-Filho, G.M.; Moraes, F.C.; Brasileiro, P.S.; Salomon, P.S.; Mahiques, M.M.; Bastos, A.C.; Almeida, M.G.; Silva, J.M.; Araujo, B.F., Jr.; et al. An extensive reef system at the Amazon River mouth. Sci. Adv. 2016, 2, e1501252. [CrossRef]

19. Coutinho, P.N.; Morais, J.O. Distribución de los sedimentos en la plataforma continental norte y nordeste del Brasil. Arq. Ciên. Mar. 1970, 10, 79-90.

20. Foster, M.S. Rhodoliths: Between rocks and soft places. J. Phycol. 2001, 37, 659-667. [CrossRef]

21. Amado-Filho, G.M.; Bahia, R.G.; Pereira-Filho, G.H.; Longo, L.L. South Atlantic rhodolith beds: Latitudinal distribution, species composition, structure and ecosystem functions, threats and conservation status. In Rhodolith/Maërl Beds: A Global Perspective; Riosmena-Rodríguez, R., Nelson, W., Aguirre, J., Eds.; Springer International Publishing (Coastal Research Library): London, UK, 2017; pp. 299-317.

22. Mahiques, M.M.; Siegle, E.; Francini-Filho, R.B.; Thompson, F.L.; De Rezende, C.E.; Gomes, J.D.; Asp, N.E. Insights on the evolution of the living Great Amazon Reef System, equatorial West Atlantic. Sci. Rep. 2019, 9, 13699. [CrossRef]

23. Cruz, R. Manual de Métodos de Muestreo para la Evaluación de las Poblaciones de Langosta Espinosa; FAO Documento Técnico de Pesca; FAO: Rome, Italy, 2002; pp. 1-43.

24. Chan, T.Y. Updated checklist of the world's marine lobsters. In Lobsters: Biology, Fisheries and Aquaculture; Radhakrishnan, E.V., Phillips, B.F., Achamveetil, G., Eds.; Springer: Singapore, 2019; pp. 35-64.

25. Diggle, P. Time Series: A Bioestatistical Introduction; Oxford University Press: Oxford, UK, 1990; 272p.

26. Rocha, L.A.; Craig, M.T.; Bowen, B.W. Phylogeography and the conservation of coral reef fishes. Coral Reefs 2007, 26, 501-512. [CrossRef]

27. Giraldes, B.W.; Smyth, D.M. Recognizing Panulirus meripurpuratus sp. nov. (Decapoda: Palinuridae) in Brazil—Systematic and biogeographic overview of Panulirus species in the Atlantic Ocean. Zootaxa 2016, 4107, 353-366. [CrossRef]

28. Sarver, S.K.; Silberman, J.D.; Walsh, P.J. Mitochondrial DNA sequence evidence supporting the recognition of two subspecies or species of the Florida spiny lobster Panulirus argus. J. Crustacean Biol. 1998, 18, 177-186. [CrossRef]

29. Sarver, S.K.; Freshwater, D.W.; Walsh, P.J. The occurrence of the provisional Brazilian subspecies of spiny lobster (Panulirus argus westonii) in Florida waters. Fish. Bull. 2000, 98, 870-873.

30. Briones-Fourzán, P.; Barradas-Ortiz, C.; Negrete-Soto, F.; Segura-García, I.; Lozano-Álvarez, E. Occurrence of Panulirus meripurpuratus and Panulirus laevicauda (Decapoda: Achelata: Palinuridae) in Bahía de la Ascensión, México. Lat. Am. J. Aquat. Res. 2019, 47, 694-698. [CrossRef]

31. Knowlton, N. Molecular genetic analyses of species boundaries in the sea. Hydrobiologia 2000, 420, 73-90. [CrossRef] 
32. Fausto-Filho, J. Sobre a ocorrência de Palinustrus truncatus (H. Milne-Edwards, 1880), no litoral brasileiro e de Panulirus echinatus Smith 1860 no litoral do Estado do Ceará, Brasil (Crustácea, Decapoda, Palinuridae). Arq. Ciên. Mar. 1977, 17, 75-76.

33. Santana, W.; Pinheiro, A.P.; Oliveira, J.E.L. Additional records of three Scyllarides species (Palinura: Scyllaridae) from Brazil, with the description of the fourth larval stage of Scyllarides species (Palinura: Scyllaridae) from Brazil, with the description of the fourth larval stage of Scyllarides aequinoctialis. Nauplius 2007, 15, 1-6.

34. Melo, G.A.S. Manual de Identificação dos Crustácea Decapoda do Litoral Brasileiro: Anomura: Thalassinidea; Palinuridea e Astacidea: Cidade de São Paulo Plêiade: São Paulo, Brazil, 1999; 551p.

35. Coelho, P.A.; Ramos-Porto, M. Sinopse de crustáceos decápodos brasileiros (famílias Scyllaridae, Palinuridae, Nephropidae, Parastacidae e Axiidae). An. Univ. Fed. Rural. Pernamb. 1985, 8, 38-47.

36. Tavares, M.; Santana, W.; Pinheiro, A. On the type material of Scyllarides Deceptor, Holthuis, 1963 (Crustacea: Decapoda: Scyllaridae). Papéis Avulsos Zool. (Museo Zool. Univ. São Paulo) 2009, 49, 539-545. [CrossRef]

37. Oliveira, G.; Freire, A.S.; Bertuol, P.R.K. Reproductive biology of the, slipper lobster Scyllarides deceptor (Decapoda:Scyllaridae) along the southern Brazilian coast. J. Mar. Biol. Assoc. 2008, 88, 1433-1440. [CrossRef]

38. Duarte, L.F.A.; Severino-Rodrigues, E.; Gasalla, M.A. Slipper lobster (Crustacea, Decapoda, Scyllaridae) fisheries off the southeastern coast of Brazil: I. Exploitation patterns between $23^{\circ} 00^{\prime}$ and $29^{\circ} 65^{\prime}$ S. Fish. Res. 2010, 102, 141-151. [CrossRef]

39. Tavares, M. Scyllarus ramosae, new species, from the Brazilian continental slope, with notes on congeners occurring in the area (Decapoda: Scyllaridae). J. Crustacean Biol. 1997, 17, 716-724. [CrossRef]

40. Tavares, C.R.; Young, P.S. Nephropidae (Crustacea, Decapoda) collected by the Revizee Score-Central Program from off Bahia to Rio de Janeiro states, Brazil. Arq. Mus. Nac. 2002, 60,77-88.

41. Schmitt, W. Crustacea Macrura and Anomura of Porto Rico and the Virgin Islands-Scientific Survey of Porto Rico and Virgin Islands. N. Y. Acad. Sci. 1935, 15, 125-262.

42. Robertson, P.B. The early larval development of the Scyllarid lobster Scyllarides aequinoctialis (Lund) in the laboratory, with a revision of the larval characters of the genus. Deep Sea Res. 1969, 16, 557-586. [CrossRef]

43. Dall'Occo, P.L.; Bento, R.T.; Melo, G.A.S. Range extensions for lobsters off the Brazilian Coast (Crustacea, Decapoda, Palinura, Astacidea). Biociências 2007, 15, 47-52.

44. Dall'Occo, P.L. Taxonomia e Distribuição das Lagostas (Crustacea: Decapoda: Achelata e Polychelida) no Oceano Atlântico. Ph.D. Thesis, Universidade Estadual Paulista, Rio Claro, Brazil, 2010; 432p.

45. Coelho, P.A.; Almeida, A.O.; Bezerra, L.E.A.; Souza-Filho, J.F. An updated checklist of decapod crustaceans (infraorders Astacidea, Thalassinidea, Polychelida, Palinura, and Anomura) from the northern and northeastern Brazilian coast. Zootaxa 2007, 1519, 1-16.

46. Serejo, C.S.; Young, P.S.; Cardoso, I.C.; Tavares, C.; Rodrigues, C.; Almeida, T.C. Abundância, diversidade e zonação dos crustáceos no talude da costa central do Brasil $\left(11^{\circ}-22^{\circ} \mathrm{S}\right)$ coletados pelo programa REVIZEE $\backslash$ Score Central: Prospecção pesqueira. In Biodiversidade da Fauna Marinha Profunda na Costa Central Brasileira; Costa, P.A.S., Olavo, G., Martins, A.S., Eds.; Rio de Janeiro Museo Nacional: Cidade de Rio de Janeiro, Brazil, 2007; pp. 133-162.

47. Silva, K.C.A.; Fransen, C.H.J.M.; Ramos-Porto, M.; Paiva, K.S.; Cintra, I.H.A.; Cruz, R. Report of Scyllarus chacei, Holthuis, 1960 (Decapoda, Scyllaridae) in Amapá state sontinental shelf of Brazil. Crustaceana 2012, 85, 1171-1177.

48. Alves-Junior, F.A.; Araujo, M.S.L.C.; Souza-Filho, J.F. Distribution of two species of Nephropsis Wood-Mason, 1872 (Crustacea: Decapoda: Nephropidae) from northeastern Brazil. Zootaxa 2016, 4114, 090-094. [CrossRef]

49. Tavares, M. Malacostraca-Eucarida. Nephropidae. In Catalog of Crustacea from Brazil; Young, P., Ed.; Museu Nacional: Rio de Janeiro, Brazil, 1999; pp. 377-378.

50. Silva, K.C.A.; Cintra, I.H.A.; Ramos-Porto, M.; Viana, G.F.S. Lagostas capturadas durante pescarias experimentais para o programa Revizee/Norte. (Crustacea, Nephropoidea, Eryonoidea, Palinuroidea). Bol. Téc. Cient. Cepnor Belém 2003, 3, 21-35.

51. Galil, B.S. Crustacea Decapoda: Review of the genera and species of the family Polychelidae Wood-Mason, 1874. In Résultats des Campagnes Musorstom; Crosnier, A., Ed.; Mémoires du Muséum National d'Histoire Naturelle: Paris, France, 2000 ; pp. $285-387$.

52. Gaeta, J.C.; Silva, M.B.; Godoy, T.; Cruz, R. Update on the lobster species from Rocas Atoll Marine Reserve, Brazil. Check List 2015, 11, 1-7. [CrossRef]

53. Severino-Rodrigues, E.; Hebling, N.J.; Melo, G.A.S.; Graça-Lopes, R. Biodiversidade no produto da pesca dirigida ao lagostim Metanephrops rubellus (Moreira,1903) no litoral do Estado de São Paulo, Brasil, com ênfase à carcinofauna. Inst. Pesca 2007, 33, $171-182$.

54. Cruz, R.; Conceição, R.N.L.; Marinho, R.A.; Barroso, J.C.; Holanda, J.S.; Félix, C.S.; Martins, M.E.O.; Santos, F.S.; Silva, K.C.A.; Furtado-Neto, M.A.A. Metodologias de amostragem para avaliação das populações de lagosta: Plataforma Continental do Brasil. Edição bilingüe português/espanhol). Colecao Habitat 2011, 6, 1-142.

55. Silva, K.C.A.; Cintra, I.H.A.; Ramos-Porto, M.; Viana, G.F.S. Lagostas capturadas na plataforma continental do estado do Amapá (Crustacea, Nephropoidea, Palinuroidea). Bol. Téc. Cient. Cepnor Belém 2007, 7, 173-184. [CrossRef]

56. Cruz, R.; Baisre, J.A.; Díaz, E.; Brito, R.; Blanco, W.; García, C.; Carrodeguas, C. Atlas Biológico-Pesquero de la Langosta en el Archipiélago Cubano; Revista Mar y Pesca: Ciudad Habana, Cuba, 1990; 125p.

57. Puciarelly, P.; Rego, A.B. The Crustacean Collection, Museum National d'Histoire Naturelle. Paris, France. 2020. No Restrictions to Copy and Redistribute the Material in Any Medium or Format. Available online: https://creativecommons.org/licenses/by/ 4.0/ deed.en (accessed on 15 August 2021). 
58. Legall, N.; Poupin, J. CRUSTA: Database of Crustacea (Decapoda and Stomatopoda), with Special Interest for Those Collected in French Overseas Territories. 2021. Available online: http:/ / crustiesfroverseas.free.fr/ (accessed on 15 August 2021).

59. Scarabino, F. Metanephrops rubellus (Moreira, 1903). (scampi, cigala, Uruguayan lobster). Photography of the body in dorsal view. Annotated catalogue and bibliography of marine and estuarine shrimps, lobsters, crabs and their allies (Crustacea: Decapoda) of Argentina and Uruguay (Southwestern Atlantic Ocean). In Frente Marítimo; 2019; Volume 26, 179p.

60. Felder, D.L. The emergence of lobsters: Phylogenetic relationships, morphological evolution and divergence time comparisons of an ancient group (decapoda: Achelata, astacidea, glypheidea, polychelida). Syst. Biol. 2014, 63, 457-479.

61. Ahyong, S.T.; Shan, T.Y. Polychelidae from the Bohol and Sulu seas collected by Panglao 2005 (Crustacea: Decapoda: Polychelidae). Raffles Bull. Zool. 2008, 19, 63-70.

62. Lavalli, K.L.; Spanier, E. The biology and fisheries of the slipper lobster. In Crustaceans; Von, R., Ed.; CRC Press: Leiden, The Netherlands, 2007; 420p.

63. Fischer, W. Lobsters: FAO Species Identification Sheets for Fishery Purposes; FAO: Rome, Italy, 1978; 1700p.

64. Takeda, M. Crustaceans. In Crustaceans and Mollusks Trawled off Suriname and French Guiana; Takeda, M., Okutani, T., Eds.; Japan Marine Research Center: Tokyo, Japan, 1983; 354p.

65. Fonteles-Filho, A.A. Population dynamics of spiny lobsters (Crustacea: Palinuridae) in Norhteast Brazil. Ciência Cultura 1992, 44, 192-196.

66. Cruz, R.; Silva, K.C.A.; Gaeta, J.C.; Santana, J.V.M.; Cintra, I.H.A. Reproductive potential and stock recruitment of the Caribbean and Brazilian metapopulations of the spiny lobster, Panulirus argus (Latreille, 1804). Crustaceana 2014, 87, 1315-1337. [CrossRef]

67. Cintra, I.H.A.; Martins, D.E.G.; Alves-Júnior, F.A.; Santos, W.C.R.; Valente, H.M.; Klautau, A.G.C.M.; Silva, K.C.A. Report of the sculptured slipper lobster Parribacus antarcticus (Lund, 1793) (Decapoda: Scyllaridae) on the Great Amazon Reef System, Pará, Brazil. Bol. Téc. Cient. Cepnor Belém 2003, 3, 21-35.

68. Lipcius, R.N.; Herrnkind, W.F. Control and coordination of reproduction and molting in the spiny lobster Panulirus argus. Mar. Biol. 1987, 96, 207. [CrossRef]

69. Cruz, R. Fecundidad y madurez sexual en la langosta comercial Panulirus argus (Latreille, 1804) Crustácea: Palinuridae en Cuba. Rev. Cubana Investig. Pesq. 1980, 5, 2-27.

70. MacDiarmid, A.B.; Kittaka, J. Breeding. In Spiny Lobsters: Fisheries and Culture, 2nd ed.; Phillips, B.F., Kittaka, J., Eds.; Fishing News Books; Blackwell Science: Oxford, UK, 2000; pp. 485-507.

71. Sekiguchi, H.; Booth, J.D.; Webber, W. Early Life Histories of Slipper Lobsters. In The Biology and Fisheries of the Slipper Lobster. Lavalli, K.L., Spanier, E., Eds.; CRC Press: Leiden, The Netherlands, 2007; pp. 69-90.

72. Johnson, M.W. The phyllosoma larvae of slipper lobsters from the Hawaiian Islands and adjacent areas (Decapoda, Scyllaridae). Crustaceana 1971, 20, 77-103. [CrossRef]

73. Palero, A.F.F.; Guerao, G.B.; Hall, M.C.; Chan, T.Y.D.; Clark, P.F.E. The 'giant phyllosoma' are larval stages of Parribacus antarcticus (Decapoda: Scyllaridae). Invertebr. Syst. 2014, 28, 258-276. [CrossRef]

74. Buesa, R.J. Biologia de la langosta Panulirus argus, Latreille, 1804 (Crustacea, Decapoda, Reptantia) en Cuba; INPP/CIP: Ciudad Habana, Cuba, $1965 ; 228$.

75. Munro, J.L. The Biology, Ecology, Exploitation and Management of Aribbean Reef Fishes: Crustaceans (Spiny Lobsters and Crabs); Zoology Department, University of the West Indies: Kingston, Jamaica, 1974; pp. 1-51.

76. Aitken, K.A. Jamaica Spiny Lobster Investigations; FAO Fish. Rep.; FAO: Rome, Italy, 1977; pp. 11-22.

77. Kanciruk, P. Ecology of juvenile and adult Palinuridae (spiny lobsters). In The Biology and Management of Lobster; Cobb, J.S., Phillips, B.F., Eds.; Academic Press: New York, NY, USA, 1980; Volume 2, Part 1; pp. 59-92.

78. Cruz, R.; Brito, R.; Díaz, R.; Lalana, R. Ecología de la langosta (Panulirus argus) al SE de la Isla de la Juventud. II. Patrones de movimiento. Rev. Investig. Mar. 1986, 7, 19-35.

79. Cruz, R.; Phillips, B.F. The artificial shelters (pesqueros) used for the spiny lobster (Panulirus argus) fisheries in Cuba. In Spiny Lobster Management: Fisheries and Culture, 2nd ed.; Phillips, B.F., Kittaka, J., Eds.; Blackwell: Oxford, UK, 2000 ; pp. 400-419.

80. Joll, L.M. The Predation of Pot Caught Western Rock Lobster (Panulirus fongipes cygnus) by Octopus; Department of Fisheries and Wildlife: Washington, DC, USA, 1977; pp. 1-58.

81. Ivo, C.T.C. Estudo Sobre la Biologia da Pesca do Pargo Lutjanus Purpureus Poey, No Nordeste Brasileiro, Arquivo de Ciências do Mar; Universidade Federal do Ceará (UFC): Fortaleza, Brazil, 1973; Part 2; pp. 113-116.

82. Ivo, T.; Hanson, A.J. Aspectos da Biologia e Dinâmica Populacional do Pargo, Lutjanus purpureus Poey, no Norte e Nordeste do Brasil. Arq. Ciên. Mar, Fortaleza 1982, 22, 1-4.

83. Pinheiro, R.; Silva, K.C.A. Dinâmica Alimentar do Pargo Lutjanus purpureus (Poey, 1875) Capturado na Plataforma Continental Amazônica. Bachelor's Thesis, Universidade Federal Rural da Amazônia, Belém, Brazil, 2019; 37p.

84. Silva, B.B.; Aragão, J.A.N.; Freire, J.L.; Lutz, I.A.F.; Sarmento, G.C.; Gomes, T.; Lima, W.P.G.; Santos, R.R.F. Documento Técnico Sobre a Situação Atual das Pescarias do Pargo na Região Norte do Brasil; Universidade Federal do Pará—Campus Bragança Instituto de Estudos Costeiros Laboratório de Bioecologia Pesqueira_LABIP: Ciudade de Bragança, Brazil, 2017; 132p.

85. Monteiro-Filho, E.L.; Oliveira, L.V.; Monteiro, K.D.K.A.; Filla, G.F.; Quito, L.; Godoy, D.F. Guia ilustrado mamíferos marinhosBrasil. In Projeto Boto-Cinza; Instituto de Pesquisas de Cananéia (IPeC): Ciudad de São Paulo, Brazil, 2013; 106p. 
86. Gupta, K.S.; Kizhakudan, S.J.; Kizhakudan, J.K.; Myousuf, K.S.S.; Raja, S. Preliminary observations on dominance of crustacean larvae in the diet of little tunny Euthynnus affinis (Cantor, 1849) caught off Chennai and Cuddalore coasts. Indian J. Fish 2014, 61, $40-44$.

87. Werth, A. Feeding in marine mammals. In Feeding. Chapter 16; Hampden-Sydney College: Sindey, Australia, $2000 ;$ pp. 487-526.

88. Herrera, A.; Diaz-Iglesias, E.; Brito, R.; González, G.; Gotera, G.; Espinosa, J.; Ibarzábal, D. Alimentación natural de la langosta Panulirus argus en la región de los Indios (plataforma SW de Cuba) y su relación con el bentos. Rev. Investig. Mar. 1991, 12, 172-182.

89. Cox, C.; Hunt, J.H.; Lyons, W.G.; Davis, G.E. Nocturnal foraging of the Caribbean spiny lobster (Panulirus argus) on offshore reefs of Florida, USA. Mar. Freshw. Res. 1997, 48, 671-680. [CrossRef]

90. Lewis, J.B. The phyllosoma larvae of the spiny lobster Panulirus argus. Bull. Mar. Sci. 1951, 1, 78-103.

91. Goldstein, J.S.; Matsuda, H.; Takenouchi, T. A description of the complete development of larval Caribbean spiny lobster, Panulirus argus (Latreille, 1804) in culture. J. Crust. Biol. 2008, 28, 306-327. [CrossRef]

92. Greer, A.T.; Briseño-Avena, C.; Deary, A.L.; Cowen, R.K.; Herandez, F.J.; Graham, W.M. Associations between lobster phyllosoma and gelatinous zooplankton in relation to oceanographic properties in the northern Gulf of Mexico. Fish. Oceanogr. 2017, 26, 693-704. [CrossRef]

93. Chow, S.; Suzuki, S.; Matsunaga, T.; Lavery, S.; Jeffs, A.G. Investigation on natural diets of larval marine animals using peptide nucleic-directed Polymerase Chain Reaction clamping. Mar. Biotechnol. 2010, 13, 305-313. [CrossRef] [PubMed]

94. O'Rorke, R.; Lavery, S.; Chow, S.; Takeyama, H.; Tsai, P.; Beckley, L.E.; Thompson, P.A.; Waite, A.M.; Jeffs, A.G. Determining the diet of larvae of Western Rock Lobster (Panulirus Cygnus) using High-Throughput DNA Sequencing Techniques. PLoS ONE 2012, 7, e42757. [CrossRef] [PubMed]

95. Phillips, B.F.; Mcwilliam, P.S. The pelagic phase of spiny lobster development. Can. J. Fish. Aquat. Sci. 1986, 43, $2153-2163$. [CrossRef]

96. Wakabayashi, K.; Yang, C.-H.; Chan, T.Y.; Phillips, B.F. The final phyllosoma, nisto, and first juvenile stages of the slipper lobster Petrarctus brevicornis (Holthuis, 1946) (Decapoda: Achelata: Scyllaridae). J. Crustacean Biol. 2020, 40, 237-246. [CrossRef]

97. Lalana, R.; Ortiz, M. Contenido estomacal de puérulos y post-puérulos de la langosta Panulirus argus en el Archipiélago de los Canarreos, Cuba. Rev. Investig. Mar. 1991, 12, 107-116.

98. Francini-filho, R.B.; Asp, N.E.; Siegle, E.; Hocevar, J.; Lowyck, K.; D’Avila, N.; Vasconcelos, A.S.; Baitelo, R.; Rezende, C.E.; Omachi, C.Y.; et al. Perspectives on the Great Amazon Reef: Extension, biodiversity and threats. Front. Mar. Sci. 2018, 5, 103-123. [CrossRef]

99. Muricy, G.; Moraes, F.C. Marine sponges of Pernambuco State, NE Brazil. Rev. Bras. Oceanogr. 1998, 46, 213-217. [CrossRef]

100. Muricy, G.; Lopes, D.A.; Hajdu, E.; Carvalho, M.S.; Moraes, F.C.; Carla, M.K.; Pinheiro, M.U. Catalogue of Brazilian Porifera; Museo Nacional Livros Serie: Recife City, Brazil, 2011; Volume 46, 300p.

101. Caddy, J.F. Why do assessments of demersal stocks largely ignore habitat? ICES J. Mar. Sci. 2014, 71, 2114-2126. [CrossRef]

102. Igarashi, M.A. Note on photographic register and preliminary observations from puerulus to juvenile of Panulirus argus after settlement in Amansia sp. macroalgae in Brazil. Ciências Agrárias Londrina 2010, 31, 767-772. [CrossRef]

103. Oliveira, G. A Pesca da Lagosta Sapatera Scyllarides Deceptor HOLTHUIS, 1963 (CRUSTACEA: DECAPODA:SCYLLARIDAE) no sul do Brasil-Subsídios ao Conhecimiento da Biologia Reprodutiva e à Conservação da Espécie. Tese Apresentada como Requisito Parcial à Obtenção do grau de Mestre em Ciências Biológicas-Área de Concentração Zoologia; Programa de Pós-graduação em Zoologia, Setor de Ciências Biológicas da Universidade Federal do Paraná: Curitiba, Brazil, 2008; pp. 1-62.

104. Linderman, K.; Lee, T.N.; Wilson, W.D.; Claro, R.; Jerald, A. Transport of Larvae Originating in Southwest Cuba and the Dry Tortugas: Evidence for Partial Retention in Grunts and Snappers; Gulf and Caribbean Fisheries Institute: Corpus Christi, TX, USA, 2001 ; pp. $732-747$.

105. Jeffs, A. Revealing the natural diet of the phyllosoma larvae of spiny lobster Bull. Fish. Res. Agen. 2007, 20, 9-13.

106. Larrañeta, M.G. Ecología de la relación stock-reclutamiento en los peces marinos. Oceanides 1986, 11, 55-187.

107. Doi, M.; Ohno, A.; Kohno, H.; Taki, Y.; Singhagraiwan, T. development of feeding ability in red snapper Lutjanus argentimaculatus early larvae. Fish. Sci. 1997, 63, 845-853. [CrossRef]

108. Cruz, R.; Adriano, R. Regional and seasonal prediction of the Caribbean lobster (Panulirus argus) commercial catch in Cuba. Mar. Freshwat. Res. 2001, 52, 1633-1640. [CrossRef]

109. Lang, J.M.; Benbow, M. Species Interactions and Competition. Nat. Educ. Knowl. 2013, 4, 1-8. 